\title{
OS DOMÍNIOS RECALCITRANTES DO DIREITO INTERNACIONAL: DIVERSIDADE MORAL E RELIGIOSA NO DIREITO PENAL COMO ÓBICE AO DIREITO COMUM: O CASO DO ABORTO DO FETO ANENCÉFALO
}

\author{
GEILZA FÁTIMA CAVALCANTI DINIZ ${ }^{1}$
}

\begin{abstract}
RESUMO: A religião e a moral são domínios recalcitrantes aos processos de internacionalização do direito. No presente trabalho, estuda-se a influência desses temas no caso da interrupção da gravidez do feto anencéfalo, a partir do estudo de casos nos Estados Unidos, Argentina e Brasil e da análise do ordenamento jurídico holandês para verificar essa tensão e mostrar possíveis soluções ao problema. PALAVRAS-CHAVE: Direito Internacional; Religião; Moral; Aborto do Feto Anencéfalo; Margem Nacional de Apreciação.
\end{abstract}

ABSTRACT: Religion and morality are recalcitrant areas to processes of internationalization of law. In this paper, we study the influence of these issues in the case of termination of pregnancy of anencephalic fetus, from the case studies in the United States, Argentina and Brazil and analysis of the Dutch legal system to check the tension and show possible solutions to problem.

KEYWORDS: International Law; Religion; Moral; Abortion Anencephalic Fetus; National Margin of Appreciation.

SUMÁRIO: Introdução; Os Domínios Recalcitrantes; A Interrupção da Gravidez do Feto Anencéfalo; O Aborto na Holanda; O Aborto do Anencéfalo nos Estados Unidos da América: caso Britell v. Estados Unidos da América; O Aborto do Anencéfalo na Argentina: Caso Silvia Tanus v. Governo de Buenos Aires; O Aborto do Anencéfalo no Brasil; Dos Processos de Interação no Direito Internacional; A Margem Nacional de Apreciação; Conclusões; Referências Bibliográficas.

SUMMARY: Introduction; The Recalcitrant Areas; The Interruption of Pregnancy of Anencephalic Fetus; Abortion in the Netherlands; Abortion in the United States of America: Case Britell v. United States of America; The Abortion of Anencephalic in Argentina: If you see Sylvia Tanus Government of Buenos Aires; Abortion in Brazil; Processes of Interaction in International Law; The National Margin of Appreciation; Conclusions; Bibliographical References.

Artigo recebido em 16.12.2010. Pareceres emitidos em 05.08.2011 e 29.07.2011.

Artigo aceito para publicação em 05.09.2011.

${ }^{1}$ Doutoranda em Direito das Relações Internacionais (UNICEUB - Centro Universitário de Brasília

- Brasília/DF), Mestra em Direito Público (UFPE - Recife/PE), Juíza de Direito (TJDFT Tribunal de Justiça do Distrito Federal e Territórios - DF). geilza@tjdft.jus.br 


\section{INTRODUÇÃO}

Globalização e fragmentação, universalismo e relativismo são eventos que, embora pareçam excludentes, em realidade são complementares, conceitos multívocos ou de geometria variável ${ }^{2}$ e que, portanto, não podem ser estudados isoladamente. Não se pode mais pensar em um direito internacional que vise ao universalismo no sentido forte da palavra, ou seja, como um direito comum aplicado a todos os povos, pois não podem ser olvidadas as características singulares de cada nação. Por outro lado, a soberania não pode constituir uma escusa para justificar a perpetração de atos ofensivos à dignidade da pessoa humana, e a exigência de observância da diversidade local a qualquer custo tornaria impossível o relacionamento com o outro. O meio termo entre esses dois aspectos tem sido o grande desafio do direito internacional contemporâneo.

É necessário então trabalhar com o conceito de tolerância, que emerge exatamente da tensão entre identidade e diversidade ${ }^{3}$ e que, como postulado de reconhecimento da diversidade cultural, contrapõe-se à hegemonia de valores. O conceito de tolerância não prescinde de uma análise histórica e de uma análise comparativa de realidades locais. Tem suas raízes fincadas especialmente no movimento religioso do período medieval. Portanto, a análise da tolerância deve partir do estudo da influência das religiões e, ao se fazê-lo, verifica-se que há domínios recalcitrantes até os dias atuais, decorrentes de crenças profundas, ligadas à moral e a religião ${ }^{4}$.

Exemplo da importância do estudo das particularidades locais de cada nação é o debate acerca da interrupção da gravidez do feto anencéfalo. Estando esse debate inserido no binômio nascimento e morte de seres humanos, verifica-se que não é ele um simples evento natural, mas sim um acontecimento permeado por fatores culturais, religiosos, morais, jurídicos e éticos. O binômio vida e morte resta então profundamente marcado pela

\footnotetext{
2 SAN JOSÉ, Daniel García. Unilateralismo y Multilateralismo como Concepctos de Geometria Variable en la Sociedad Internacional Poscontemporánea. Disponível em www.reei.org., acesso em 05 nov. 2010.

${ }^{3}$ A noção trabalhada nesse artigo é aquela relativa às éticas da identidade e da diversidade, isto é, da identidade como o igual e da diversidade como o diferente, nesse sentido, Clodoaldo Meneguelo Cardoso, in Tolerância e seus Limites: um olhar latino-americano sobre diversidade e igualdade, São Paulo: Editora Unesp, 2003, p. 17 esclarece que "outro aspecto a ser avaliado é a própria crítica ao lluminismo, visto como vertente moderna da ética da identidade. O questionamento do racionalismo dogmático, fonte de intolerância, acabou estendendo-se à própria razão. Para essa posição, nós somos o que somes muito mais por aquilo que temos de diferente do que por aquilo que temos em comum. Em última instância, a cultura existe apenas no plural e por isso somente se pode conceber a tolerância no interior da ética da diversidade. Em outras palavras, essa virtude será alcançada não pela consciência do que temos em comum (porque quase nada temos em comum), mas pela sensibilidade em relação a nossas diferenças. ...Assim sendo, o sentido da tolerância deverá emergir da tensão entre identidade e diversidade, como veremos, passando necessariamente pelo debate sobre as desigualdades sociais. Isso implica, portanto, uma atenção especial ao se trabalhar esse valor ético na educação".

${ }^{4} \mathrm{O}$ estudo da moral como parte da religião ou vice-versa não é o objeto central do presente trabalho. Portanto, a análise desses dois fatores será feita como aspectos independentes entre si.
} 
diversidade cultural dos países, ao mesmo tempo em que é fortemente perturbado pelas incertezas científicas. A guerra entre os grupos antiaborto e seus adversário já chegou a ser inclusive comparada com uma versão norteamericana das guerras civis religiosas da Europa do século XVII ${ }^{5}$.

É preciso então estudar o valor da vida e suas implicações moral, religiosa, política e internacional nesses domínios recalcitrantes, para que se estude o papel dos Estados e do Direito face ao problema da diversidade. Portanto, ao pensar em harmonização do direito penal em assuntos ligados à vida e à morte, tais como aborto e eutanásia, o estudo deve ser permeado da análise da história de cada povo, que pode conduzir a uma impossibilidade de harmonização das legislações dos Estados, ao menos substancialmente.

Ora, se a solução a tais dilemas não se encontra estabilizada dentro dos próprios Estados e se os temas ligados à vida ou morte dependem fortemente de fatores religiosos, culturais, morais etc, como se pretender uma universalização? Seria possível pretender respostas universalizáveis nos domínios da vida e morte? Ou a pretensa comunidade mundial de valores encontra limites exatamente nesses domínios? Para tratar do tema, no presente estudo analisar-se-á o caso do aborto do feto anencéfalo e o tratamento dado ao tema em algumas instâncias internacionais, para fazer uma relação entre esse tratamento pelo direito e a influência religiosa e de valores morais subjacentes nos diversos ordenamentos.

Essa temática demonstra a existência de formas híbridas de miscigenação cultural $^{6}$, ou seja, conflitos multiculturais que decorrem da mundialização do direito e da diluição das fronteiras, próprias do mundo internacionalizado ${ }^{7}$ que vivemos. Aliás, a própria noção de estado democrático se relaciona com a inexistência de uma concepção uniforme da moral ${ }^{8}$, ou seja, de um pluralismo moral e de um espírito de abertura. A dificuldade se apresenta porque, em temas profundamente marcados por valores religiosos, constata-se que o dever religioso e a liberdade são dificilmente conciliáveis; o dever religioso, por sua natureza, implica na submissão de uma pessoa às regras divinas, enquanto a liberdade pressupõe que um máximo de faculdades e de escolhas seja dado ao indivíduo. É nesse cenário que deve ser estudada a questão da interrupção da gravidez do feto anencéfalo.

O simples diálogo entre juízes, ou comércio de juízes, não é suficiente, não responde às questões dos necessários limites ao pluralismo. Por isso, faz-se necessário estudar mecanismos de convivência entre as ordens

\footnotetext{
${ }^{5}$ DWORKIN, Ronald. Domínio da Vida: aborto, eutanásia e liberdades individuais. São Paulo: Matins Fontes, 2009, p. 2-3.

${ }^{6}$ HABERMAS, Jürgen. A Era das Transições. Rio de Janeiro: Tempo Brasileiro, 2003, p. 104.

7 Prefere-se a distinção entre globalização e mundialização como sendo aquela relativa ao direito privado, especialmente ao comércio e economia e a mundialização relativa aos direitos humanos, ambas como espécies da internacionalização do direito.

${ }^{8}$ DELMAS-MARTY, Mireille. Les Forces Imaginantes du Droit (II). Le pluralisme Ordoné. Paris: Seuil, 2005, p. 84.
} 
jurídicas agonísticas ${ }^{9}$, em prol de uma internacionalização do direito que preserve as identidades culturais e que responda aos desafios da modernidade, especialmente na seara da bioética, que parece desconhecer as fronteiras territoriais.

Inicialmente, abordar-se-á a problemática dos domínios recalcitrantes como limites ao direito internacional para, em seguida, identificar o caso específico da interrupção da gravidez do feto anencéfalo como um tema inserido nesse debate e que, portanto, sofre profundas influências das crenças religiosas e morais. Para comprovar a hipótese, serão estudados casos judicialmente decididos sobre o aborto do feto anencéfalo nos Estados Unidos, na Argentina, no Brasil e o exemplo da legislação holandesa. Procura-se, com tal escolha, abordar o tema na perspectivas de países que tratam o tema de maneira diversa, com nítida influência dos domínios recalcitrantes no tratamento dado ao aborto do anencéfalo. A pesquisa, longe de pretender dar uma resposta com pretensão de correta sobre o tema ou de esgotar o tema, pretende apenas comprovar a hipótese de que a religião e a moral não podem ser apartadas da discussão e argumentação jurídica, especialmente no que tange às normas penais incriminadoras. Em seguida, estudar-se-ão os processos de interação da internacionalização do direito para se tentar analisar qual desses modelos é o mais adequado para responder aos desafios dos domínios recalcitrantes. Ao fim, serão apontadas algumas soluções que podem ser aplicadas para superar ou minimizar o problema, sem diminuir a importância das diversidades locais, por intermédio da margem nacional de apreciação.

\section{OS DOMÍNIOS RECALCITRANTES}

Os temas ligados à religião e à moral são domínios recalcitrantes ao direito internacional, no sentido de que, neles, a tentativa de unificação é mais tormentosa, os países não tem uma disponibilidade em aceitar valores diferentes dos seus próprios, sobretudo em temas fundantes de suas culturas. Não se pode ignorar o potencial de transformação e subversão sociocultural e política inerentes, especialmente, a grupos religiosos e movimentos sociais ${ }^{10}$. Por isso, é preciso trazer para a esfera pública discursiva o estudo desses domínios. Não se pode, pois, supor, como tradicionalmente foi feito pela teoria da argumentação jurídica ${ }^{11}$, que a religião e a moral estão

\footnotetext{
${ }^{9}$ MOUFFE, Chantal. The Return of the Political. Londres: Verso, 1993, 2005, p. 1.

${ }^{10}$ OLIVEIRA, Nythamar. Habemus Habermas: O Universalismo Ético entre o Naturalismo e a Religião. Porto Alegre: Veritas, v. 54, $\mathrm{n}^{\circ}$ 1, jan./mar. 2009, p. 217-237.

${ }^{11}$ Pretendendo-se demonstrar que o discurso jurídico pode ser fundamentado racionalmente, olvida-se e rechaça-se tudo o que não é racional e, portanto, são considerados irracionais, para a maior parte dos filósofos, o sentimentos, as emoções e as convicções pessoais, que podem estar subjacentes às decisões judiciais. Em outras palavras, partindo do pressuposto do direito como ciência, a teoria da argumentação jurídica postula a racionalidade das decisões judiciais, por intermédio de uma argumentação pertinente, que possibilite o controle dessa racionalidade do discurso. O pressuposto é que as decisões jurídicas sejam corretas no que tange às pressuposições da ordem jurídica vigente, com base em uma justificação racional, que envolve
} 
relegadas à esfera privada. Para entender os limites do direito internacional, o estudo histórico das interferências da moral e da religião é indispensável.

Após a $1^{\mathrm{a}}$ Guerra Mundial, a evolução do sistema jurídico internacional foi marcada pela busca de uma jurisdição internacional com vocação universal $^{12}$ e o conteúdo dessa jurisdição seria delineado pelos direitos do homem, conceito este que passou a ser determinado com maior solidez após os anos 90. No entanto, esses mesmos direitos do homem, pela fluidez de seus conceitos, tornaram-se óbices, em determinados assuntos, à internacionalização do direito. Isso porque particularidades locais, costumes de determinadas comunidades, faziam com que a interpretação do conteúdo desses direitos pudesse ser interpretada de maneiras diversas, e qualquer tentativa de mudança pode conduzir a um choque de civilizações (Clash of civilizations), como resposta à tentativa hegemônica das superportências ${ }^{13}$, o chamado ius americanum ${ }^{14}$, criando-se, assim, zonas de resistência.

No estudo do direito internacional, é comum se deparar com a existência de três variantes apontadas na teoria: realismo, nacionalismo e hegemonismo ${ }^{15}$. O grande erro do estudo segregado desses três paradigmas é que não é feita uma diferenciação temática entre os assuntos para que se constate se a universalização é ou não possível, em outras palavras, não se leva em consideração, via de regra, que há domínios recalcitrantes ao direito internacional, que funcionam como zonas de resistência à internacionalização do direito e que, por isso, exigem uma via alternativa de enfrentamento em face da sociedade globalizada. A lógica da coerência, portanto, deve levar em consideração a possibilidade de coesão, por intermédio do respeito à diversidade $^{16}$.

A teoria aponta uma dificuldade da passagem da pluralidade das ordens jurídicas internacionais para a unidade de uma futura ordem global $^{17}$. Essa dificuldade, com efeito, precisa ser mais bem analisada sob a ótica dos domínios recalcitrantes, para se verificar que a diversidade política, cultural e

a tomada de decisão com base na lei, nos precedentes e da dogmática. ALEXY, Robert. Teoria da Argumentação Jurídica: a teoria dos discurso racional como teoria da justificação jurídica. São Paulo: Landy, 2001, p. 321.

12 DUPUY, Pierre-Marie. L'unité de L'ordre Juridique International: cours général de droit international public (2000) / par Pierre-Marie Dupuy. Recueil des cours, Volume 297 (2002), p. 460.

13 HUNTINGTON, Samuel P., The Clash of Civilizations and the Remaking of World Order, New York, Simon \& Schuster, 1996, p. 28.

${ }^{14}$ SAN JOSÉ, Daniel García. Unilateralismo y Multilateralismo como Concepctos de Geometria Variable en la Sociedad Internacional Poscontemporánea. Disponível em www.reei.org., acesso em 05 de novembro de 2010, p. 2.

15 BOGDANDY, A. V. e DELLAVALLE, S. Universalism and Particularism as Paradigms of International Law. IILJ Working Paper 2008/3, 64 p.

${ }^{16}$ DELMAS-MARTY, Mireille. Les Forces Imaginantes du Droit (II). Le Pluralisme Ordoné. Paris: Seuil, 2005, p. 96.

${ }^{17}$ DUPUY, Pierre-Marie. L'unité de L'ordre Juridique International: cours général de droit international public (2000) / par Pierre-Marie Dupuy. Recueil des cours, Volume 297 (2002) , pp. 9-489. 
econômica observáveis nas diversas partes do mundo ocorre em velocidades diferenciadas, chamada por alguns de policronia ${ }^{18}$.

A cultura ocidental da modernidade e a instituição de uma sociedade internacional tem sido desafiada pelo ressurgimento do pluralismo religioso e cultural nas relações internacionais e que faz parte da chamada crise da modernidade, que reduz o mundo ao que pode ser controlado pela razão, ciência, tecnologia e racionalidade burocrática ${ }^{19}$, abandonando a discussão sobre religião, cultura e moralidade e suas influências no direito, especialmente no direito internacional. Assim, a ressurgência da religião no centro da discussão sobre a globalização pode ser vista como parte da busca pela autonomia e autenticidade dos países do terceiro mundo e daqueles que se revoltam contra a ocidentalização.

Por essa razão, o estudo do ressurgimento global do pluralismo religioso e cultural por intermédio das teorias do choque de civilizações, fundamentalismo ou extremismo religioso, como se o ressurgimento da religião fosse uma aberração contra o mundo moderno, deve ser feito com cautelas. A influência da religião e da moral como domínios recalcitrantes, diversamente, deve conduzir ao reconhecimento de que há múltiplas modernidades no mundo pós-moderno e que uma verdadeira sociedade internacional multicultural está sendo formada no plano internacional.

Dessa maneira, é preciso levar a sério o pluralismo religioso e moral, alçando-os ao plano da política internacional do Século XXI, pois a temática dos domínios recalcitrantes no direito internacional deve ser estudada como uma busca pela autenticidade e desenvolvimento de comunidades e estados. Seguindo a linha oposta de argumentação crítica, discutirei uma variável que Kant preferiu deixar de lado, para evitar perder o controle sobre a política, limitando-a, pois, à esfera da metafísica e que, desde então, tem sido negligenciada pelos herdeiros de Kant na investigação da paz democrática: a religião.

Desde 1970, com a revolução iraniana enviando o sinal mais visível, o mundo está testemunhando uma forte tendência para a orientação religiosa, com o crescimento de radicalismos por uma parte crescente da sua população. $\mathrm{Na}$ literatura, esta tendência é geralmente referida como o "ressurgimento da religião" ${ }^{20}$, marcada por uma busca de uma comunidade de iguais por meio da religião e não apenas por meio do Estado. Se o ressurgimento do pluralismo

\footnotetext{
${ }^{18}$ DELMAS-MARTY, Mireille. Les Forces Imaginantes du Droit (II). Le Pluralisme Ordoné. Paris: Seuil, 2005, p. 227.

${ }_{19}$ THOMAS, Scott M., Taking Religious and Cultural Pluralism Seriously: The Global Resurgence of Religion and the Transformaton of International Society, in: Millennium. Journal of International Studies, Vol. 29, № 3, 2000, 815-841.

${ }^{20}$ BAUMGART, Claudia. DEMOCRACY, DIVERSITY, AND CONFLICT: Religious Zionism and Israeli Foreign Policy. Peace Research Institute Frankfurt, CORNELL UNIVERSITY, PEACE STUDIES PROGRAM, disponível em http://www.einaudi.cornell.edu/peaceprogram/publications/ occasional_papers/Zinecker-final.pdf, acesso em 02 nov. 2010.
} 
global cultural e religioso deve ser levado a sério, então o entendimento sociológico da religião e da moral, a importância desse debate para a manutenção da autonomia e autenticidade dos Estados deve ser reconhecida como parte de qualquer ordem internacional; é o início de um pluralismo mais profundo entre estados e comunidades de uma pretensa ordem internacional.

O ressurgimento da temática da religião é visto por alguns como fonte de conflitos, porque ela promove crenças e valores que são incompatíveis com regras, práticas e normas da sociedade internacional, tais como integridade territorial, soberania do estado e não intervenção. A sociedade internacional é baseada em valores culturais e normas européias, criadas pela expansão dos estados europeus através do colonialismo e imperialismo em escala global. Mas o que antes era uma sociedade internacional européia agora deve ser visto como uma sociedade internacional mundial, com suas múltiplas diferenças ${ }^{21}$. O grande desafio da modernidade tem sido apontado como o de evitar o relativismo ético, preservando o relativismo cultural contemporâneo ${ }^{22}$, tolerando e respeitando a identidade cultural na pós-modernidade, levando-se em consideração que não há nenhuma cultura superior a outra.

O que se pretende não é recorrer ao absolutismo moral de concepções religiosas e teológicas, mas sim identificar temáticas que impedem ou dificultam a internacionalização do direito, para apontar possíveis soluções à convivência harmônica entre as diferentes realidades na seara global. Um desses temas é a antecipação do parto ou aborto do feto anencéfalo. Analisando a forma como a matéria tem sido tratada em alguns países, comparando a forma como esses países enfrentam o problema, à luz de suas fontes inspiradoras morais e religiosas, com amparo na teoria da razão moral e religiosa e o reflexo desses domínios recalcitrantes nas legislações e decisões judiciais locais ${ }^{23}$.

\section{A INTERRUPÇÃO DA GRAVIDEZ DO FETO ANENCÉFALO}

Considerando o aborto do feto anencéfalo como um domínio recalcitrante ao direito internacional, a análise de suas raízes religiosas e morais permite enfrentar o problema proposto, isto é, de que há temas que constituem óbices à uniformização do direito internacional. A forte discussão que se vê hodiernamente a respeito do aborto nem sempre esteve no centro do palco. $\mathrm{Na}$ antiga Grécia, por exemplo, as crianças indesejadas eram simplesmente abandonadas pelos pais após o nascimento. Aristóteles ${ }^{24}$ sustentava que o

\footnotetext{
${ }^{21}$ THOMAS, Scott. Religion and international conflict. In Religion and International Relations, Ed. K. R. Dark, Palgrave, 2000, p.18.

${ }^{22}$ OLIVEIRA, Nythamar. Habemus Habermas: O universalismo ético entre o naturalismo e a religião. Porto Alegre: Veritas, v. 54, nº 1, jan./mar. 2009, p. 228.

${ }_{23}$ GREEN, Ronald. Religion and Moral Reason. A New Method for Coparative Study. Nova Iorque: Oxford University Press, 1988, p. 228

${ }^{24}$ Segundo Aristóteles, em teoria adotada pela Igreja Católica, a vida era o resultado da ação de
} 
aborto era um método eficaz para limitar nascimentos e evitar o crescimento populacional exarcebado, mantendo estáveis as populações das cidades gregas $^{25}$. Platão defendia o aborto obrigatório por razões eugênicas, para mulheres com mais de 40 anos e para preservar a pureza dos guerreiros. Sócrates também defendia o aborto, desde que esse fosse o desejo da gestante. Foi com o surgimento do cristianismo que a vida passou a ser vista como um valor supremo, com ares de sacralidade e intangibilidade.

Santo Agostinho sustentava que o aborto só podia ser recriminado quando o feto recebesse alma, o que, para ele, ocorria quarenta dias após a concepção, caso fosse homem e oitenta dias após a concepção, quer se tratasse de mulher. Tempos após, a Igreja aboliu essa distinção e passou a condenar severamente qualquer tipo de aborto, assim considerado como a expulsão voluntária do feto a partir da concepção. A partir daí, a discussão sobre a origem da vida, segundo a religião, passou a ganhar mais força. E essa polêmica sobre o conceito de origem da vida, nos dias mais atuais, com o avanço da ciência permitindo a descoberta de anomalias fetais, repercutiu no caso proposto no presente estudo, ou seja, a antecipação do parto do feto anencéfalo.

O aborto decorrente de anomalia fetal, como é o caso da anencefalia, somente passou a ser discutido a partir de 1950, com o desenvolvimento de técnicas de diagnóstico pré-natal. A anencefalia é uma alteração na formação do cérebro do feto resultante da falha, nas primeiras etapas do desenvolvimento embrionário, do mecanismo de fechamento do tubo neural ${ }^{26}$. Em termos médicos, a anencefalia comporta um defeito do tubo neural caracterizado pela ausência completa ou parcial do cérebro, das meninges, do crânio e da pele. Pode ser dividida em holocrania e merocrania. A ausência de toda a calota craniana caracteriza a holocrania e a parcial, a merocrania. Trata-se de uma má-formação letal ${ }^{27}$.

A enfermidade é caracterizada pela falta de ossos cranianos, hemisférios e córtex cerebral e é letal em cem por cento dos casos. A maior parte dos fetos anencéfalos morre ainda no ventre materno, alguns vivem poucas horas após o parto, no máximo alguns dias. A morte, portanto, não é um evento possível, é uma certeza inafastável. Os casos em que os bebês vivem meses não são de anencefalia, mas de outras anomalias com definição científica diversa. Visualmente, o bebê nasce sem o cérebro, com os olhos saltados para fora, motivo pelo qual alguns afirmam que o bebê anencéfalo assemelha-se a uma rã.

um princípio ativo sobre a matéria inanimada, a qual se tornava, então, animada, por intermédio de um processo natural e não sobrenatural.

${ }^{25}$ BODÉÜS, Richard. Aristóteles, a Justiça e a Cidade. São Paulo: Ed. Loyola, 2007, p. 112.

${ }^{26}$ HERRERO, Silvina. Adelantamiento del Parto por Anencefalia del Feto. Tesina № 192 , apresentada à Facultad de Derecho y Ciencias Sociales, Carrera de Abogacía. Disponível em www.ub.edu.ar/investigaciones/tesinas/192_herrero.pdf, acesso em 03 jul. 2010.

${ }^{27}$ MORON, A. Medicina Fetal na Prática Obstétrica. São Paulo: Santos Editora, 2003. p. 173. 
A má formação do feto faz com que o sistema nervoso do bebê não se forme e, em conseqüência, inviabiliza-se a vida extra-uterina. O Brasil é o quarto país em índice de anencefalia, segundo fontes da Organização Mundial de Saúde ${ }^{28}$, dado que pode ser influenciado pelo fato de não haver, na legislação brasileira, um dispositivo claro autorizando o aborto em tais circunstâncias, como ocorre em outros ordenamentos. O diagnóstico pré-natal de anomalias fetais foi um avanço da Medicina iniciado na década de 50 nos países desenvolvidos. No entanto, em nosso país, somente em $1979^{29}$ as técnicas de diagnósticos prénatais se iniciou, passando-se a ser possível, só então, o diagnóstico seguro da anencefalia, de forma que o debate sobre a tipicidade da antecipação do parto do feto anencéfalo, no Brasil, não é antiga.

Certos autores defendem o aborto e classificam as teses contrárias a tal prática em derivativas, que seriam aquelas que pressupõem direitos e interesses que os fetos teriam desde a concepção e independentes, que seriam as teses para as quais a vida humana tem um valor intrínseco, independente de qualquer interesse ou direito particular. Afirma-se ainda que a segunda delas tem uma natureza quase religiosa e a primeira parte de uma premissa errada, pois não se trata de saber quando começa a vida humana, mas sim de saber se o feto tem interesse próprio. Nessa linha de raciocínio, o feto não teria interesse próprio, pois essa noção é ínsita à consciência e, portanto, à viabilidade, as quais somente ocorrem por volta da vigésima sexta semana de gravide $z^{30}$.

Esse argumento pode ser considerado um avanço no debate sobre o aborto do feto anencéfalo, que não tem e não virá jamais a ter consciência e, portanto, não há interesse a tutelar. Todavia, apesar de todo o seu esforço, o argumento foge da discussão sobre a violação ou não do direito à vida do anencéfalo $^{31}$, ainda que seja uma vida sem consciência ${ }^{32}$. Não é somente a vida viável que se busca proteger. Com efeito, o direito tem protegido a vida

${ }^{28}$ CARVALHO, Teresa Robichez de. A antecipação terapêutica de parto na hipótese de anencefalia fetal: estudo de casos do Instituto Fernandes Figueira e a interpretação constitucional do Tribunal de Justiça do Estado do Rio de Janeiro e do Supremo Tribunal Federal. Disponível em http://www.dominiopublico.gov.br/pesquisa/DetalheObraForm.do?select_action=\&co_obra=126556. Acesso em 27 jul. 2010, p. 69.

${ }^{29}$ MEZIARA, Flávia Corrêa. Anencefalia: análise crítica nos âmbitos médico e legal. Disponível em: http://www.dominiopublico.gov.br/pesquisa/DetalheObraForm.do?select_action=\&co_obra=116857. Acesso em 27 jul. 2010.

30 DWORKIN, Ronald. Domínio da Vida: aborto, eutanásia e liberdades individuais. São Paulo: Matins Fontes, 2009, p. 13, 19, 21 e 22.

${ }^{31}$ Biologicamente, o anencéfalo é um ser vivo até que seja declarado morto, é considerado pessoa ainda que viva pouquíssimos minutos após nascer, tanto que é necessário, após seu nascimento, seu registro de nascimento e óbito, apesar de haver uma corrente, tanto médica quanto jurídica que afirma que, como o conceito de morte em termos médicos é o de morte cerebral e o feto não tem cérebro, ele não chegaria a alcançar vida humana. Nesse sentido: REAGAN, James E. Ethics Consultation: Anencephaly and Organ Donation. The Journal of Law, Medicine \& Ethics. Disponível em <http://web.ebscohost.com/ehost/pdfviewer/pdfviewer? vid=10\&hid= $11 \&$ sid=5a4f5fbb-4b34-4aaf-9e98-c82088bad4ba\%40sessionmgr13>. Acesso em 27 jul. 2010.

${ }^{32}$ Há autores ainda que defendem que, embora tenha vida, o anencéfalo não pode ser considerado 
de animais, de plantas e pode legitimamente proteger uma vida, ainda que desprovida de interesse por não poder ser considerada humana.

$\mathrm{O}$ interesse de tutelar o direito à vida não precisa ser necessariamente do feto, pode ser do Estado, da coletividade, pois o direito avançou a tal ponto que o titular do direito não é necessariamente o detentor do interesse. Essa discussão é negligenciada ao se afirmar que as questões centrais sobre o aborto são: "quando uma criatura humana adquire interesses e direitos? Quando a vida de uma criatura humana começa a incorporar um valor intrínseco, e com quais conseqüências?" ${ }^{\prime 33}$. É possível deslocar o debate para esse ponto de vista, mas também é possível se argumentar que independente do interesse e das conseqüências, a vida deve ser tutelada, por exemplo, porque é um patrimônio comum da humanidade. E então, novamente, encontramo-nos em face de um dilema sem solução.

Ver-se-á o tratamento da questão na Holanda e, em seguida, três decisões judiciais serão analisadas para tentar comprovar da hipótese de que, quando as leis penais são influenciadas, em sua elaboração, por questões de fundo de natureza ética, moral e/ou religiosa, cria-se um obstáculo à internacionalização do direito penal. Nesses casos, a tentativa de imposição, com desrespeito à cultura e tradições locais, fomenta a criação de domínios recalcitrantes ou zonas de resistência ${ }^{34}$.

\section{O ABORTO NA HOLANDA}

Baruch Espinosa teve um papel muito importante da realidade políticojurídico holandesa, construindo uma argumentação racionalista a favor da liberdade política e religiosa, com a separação do Estado e da Igreja. Segundo o filósofo, a liberdade civil inclui necessariamente a liberdade religiosa, e suas ideias foram determinantes para que a Holanda se tornasse o país da tolerância ${ }^{35}$. Isso justifica a tranquilidade na aprovação da lei que legalizou o aborto na Holanda, em 1981. O aborto pode ser efetivado nas primeiras vinte e duas semanas de gestação, embora 95\% dos abortos sejam efetuados nas primeiras doze semanas de gravidez ${ }^{36}$.

um ser humano porque não tem memórias do tipo B, como, por exemplo, pensamentos, opiniões, atitudes ou qualquer outro tipo de atributo relacionado à vida mental, embora não se possa considerar que o anencéfalo esteja morto. Assim, não seriam pessoas. Nesse sentido: SERAFINI, Anthony. 1993. Is Coma Morally Equivalent to Anencephalia? Ethics \& Behavior 3, $n^{\circ} 2: 187$. Academic Search Complete, EBSCOhost. Acesso em 27 jul. 2010.

${ }^{33}$ DWORKIN, Ronald. Domínio da Vida: aborto, eutanásia e liberdades individuais. São Paulo: Matins Fontes, 2009, p. 29.

${ }^{34}$ DELMAS-MARTY, Mireille. Les Forces Imaginantes du Droit (II). Le Pluralisme Ordonné. Éditions du Seuil, 2006, pág. 23.

${ }^{35}$ CARDOSO, Clodoaldo Meneguello. Tolerância e seus Limites. Um Olhar Latino-americano sobre Diversidade e Desigualdade. São Paulo: Editora Unesp, p. 30.

${ }^{36}$ PINTER B, Aubeny E, Bartfai G, Loeber O, Ozalp S, Webb A. Accessibility and Availability of abortion in six European countries. European Journal of Contraception \& Reproductive Health Care [serial online]. March 2005;10(1):51-58. Available from: Academic Search Complete, Ipswich, MA. Accessed November 2, 2010, p. 52. 
A liberdade de religião é o direito fundamental explícito mais antigo garantido na Holanda e mais de um terço da população é ateia ou seguidora de religiões não cristãs. ${ }^{37}$ Após a Revolução Batavian, a separação completa entre Estado e Igreja foi consolidada e desde a Constituição de 1814 passou a ser um princípio expresso nas constituições holandesas. Na realidade, essa separação foi plantada por Espinosa, que tinha um grande grupo de amigos políticos em Amsterdã e teve uma grande amizade com o chefe do Estado Holandês, Johan de Witt. À época em que Espinosa escreveu o "Tratado Teológico-Político", o destino político da Holanda estava em jogo Espinosa se preocupou com a constituição do Estado, especificamente para que não sucumbisse à tirania e ficassem intactas a paz e a liberdade dos cidadãos, motivo pelo qual fez uma minuciosa exposição e crítica das constituições do tipo monárquico e aristocrático e reputou como imprescindível a separação entre Igreja e Estado. Suas idéias tinham enorme importância política, porque favoreciam aos partidários da república, então comandada por Johan de Witt, e contrariavam as pretensões de Guilherme III, príncipe da casa de Orange, de transformar as províncias unidas em uma monarquia ${ }^{38}$.

A base da separação postulada por Espinosa entre o Estado e a religião está em seus estudos sobre a necessidade de separação entre a Filosofia e a Teologia $^{39}$. Para ele, a teologia se apóia na autoridade daqueles que interpretam as Sagradas Escrituras para impor obediência aos homens, enquanto que a Filosofia busca a verdade, tendo, pois como autoridade a própria razão e somente a ela se submetendo. Para ele, a teologia impõe uma crença, enquanto que a filosofia deve dar ao homem a plena liberdade para pensar e agir.

O estado, assim, deve ser obra da razão e, de tal maneira, tal como a filosofia, deve se separar da religião. Da mesma forma que a filosofia, o estado deve buscar a verdade e essa busca deve ser feita com o uso da razão. Para alcançar a verdade, por meio da razão, é necessário que o homem seja livre, desprovido de superstições e vícios e essa é a base do entendimento de Espinosa no sentido da necessidade de construção de uma sociedade cuja moral seja laica, impedindo-se a submissão do homem a autoridades constituídas em ideias impostas.

Outro filósofo de grande importância na Holanda é John Locke, que durante seu exílio na Holanda, escreveu a "Epistola de Tolerantia", publicada em 1689 , sob o título de "A Letter Concerning Toleration". No texto, Locke defende a liberdade religiosa e propõe a separação total dos poderes político e religioso.

\footnotetext{
37 BIJDTERVEL, Sophie, C. Van. Freedom of religion in the Netherlands. Brigham Young University Review, 1995, v. 2, p. 555, 29 p. disponível em http://web.ebscohost.com/ehost/ delivery?vid=10\&hid=9\&sid=92f90, acesso em 20 out. 2010.

${ }^{38}$ COBRA, Rubem Queiroz. Vida, Época, Filosofia e Obras de Benedito Espinosa. Disponível em http://www.cobra.pages.nom.br/fmp-spinoza.html, acesso em 02 nov. 2010.

${ }^{39}$ DORNAS. Danilo Santos. A Separação entre a Filosofia e a Teologia segundo Spinoza. Revista Eletrônica Print by FUNREI. Metavnoia. São João del-Rei, no 3. p. 55-59, jul. 2001 Disponível em http://www.funrei.br.publicações/Metavnoia, acesso em 03 nov. 2010.
} 
Considerava ele que as guerras, torturas e execuções, em nome da religião, eram na verdade culpa da intervenção indevida de crenças religiosas no mundo político, e não do cristianismo em si. O alvo principal de Locke, portanto, era a Igreja Católica Romana, que não aceitava a separação dos poderes religioso e civil de forma alguma.

O resultado da influência desses dois filósofos no estado holandês é que o país se tornou um dos mais tolerantes, tanto em relação a imigrantes, inclusive muçulmanos, como em relação a temas ligados aos domínios recalcitrantes, permitindo o aborto e a eutanásia. Com a liberação do aborto na Holanda, tornando-o de fácil acesso, praticamente não existem abortos ilegais ou inseguros na Holanda ${ }^{40}$. $\mathrm{O}$ direito ao aborto é bem aceito na sociedade holandesa e as religiões no país (o protestantismo, catolicismo, islamismo) não interferem na política estatal sobre o aborto política e os movimentos anti-aborto têm pouco apoio na sociedade.

O aborto foi considerado ilegal na Holanda até o advento do Código Penal de 1886. A partir de então, o aborto passou a ser considerado crime, mas para tanto era necessário provar que o feto ainda estava vivo no momento do aborto. Em 1911, o "Morality Act" barrou todos os tipos de aborto, exceto para salvar a vida da mãe ${ }^{41}$. No entanto, sempre houve uma aceitação social do aborto, sendo a legislação chamada por alguns de simbólica ${ }^{42}$, e aceitação social sobre o tema aumentou consideravelmente na década de 60. A partir de 1969, houve um debate parlamentar com a visão de que a legislação sobre o aborto deveria se adaptar à realidade social, pois embora o aborto continuasse formalmente sendo um crime, a liberdade em abortar era a realidade social ${ }^{43}$.

$\mathrm{Na}$ Holanda, portanto, a questão do aborto ficou mais bem definida a partir da legalização ocorrida na década de 80 , tendo o aborto passado a ser legal mediante demanda, sem barreiras ao controle feminino de suas próprias decisões ou acesso aos serviços, pois o aborto passou a ser custeado pelo serviço público. Essa lei foi bem aceita pela população holandesa, até porque a população religiosa ortodoxa constitui a minoria. Desde 1984, não houve ameaças sérias ao direito de aborto ${ }^{44}$. Muito embora a legislação

\footnotetext{
${ }^{40}$ PINTER B, Aubeny E, Bartfai G, Loeber O, Ozalp S, Webb A. Accessibility and Availability of Abortion in six European Countries. European Journal of Contraception \& Reproductive Health Care [serial online]. March 2005;10(1):51-58. Available from: Academic Search Complete, Ipswich, MA. Accessed November 2, 2010, p. 54.

${ }^{41}$ Icon Group. Abortions: Webster's Quotations, Facts and Phrases. California: Icon Group International, 2008, p. 117.

${ }^{42}$ CHORUS, Jeroen M. J.; GERVER, P. H. M.; HONDIUS,E. H. ; RECHTSVERGELIJKING, Nederlands e Vereniging voor (ed). Introduction to Dutch law. Kluwer Law International, 2006, p. 43. ${ }^{43}$ GRIFFITHS, John Griffiths; BOOD, Alex; WEYERS, Heleen. Euthanasia and Law in the Netherlands. Amsterdã Universtiy Press, 1998, p. 45.

${ }^{44}$ OUTSHOORN, Joyce. Policy-Making on Abortion: Arenas, Actors and Arguments in the Netherlands. In Abortion politics, women's movements, and the democratic state: a comparative study of state feminism. Dorothy Mc. Bride Stetson (Ed), Ofxord University Press, 2003, p. 224.
} 
sobre o aborto só tenha entrado em vigor em 1984, no final dos anos 60 a realização de abortos em clínicas médicas era uma realidade corriqueira ${ }^{45}$.

Houve na Holanda uma outra influência no período pós-guerra: o desenvolvimento do welfare state, período no qual houve um grande esforço do estado para construir uma sociedade afluente. O governo desempenhou um importante papel, caracterizando-se como um estado providência, que deveria prover todo o tipo de assistência material em casos de necessidade. $\mathrm{O}$ crescimento do welfare state significou que o principal papel do governo era providenciar o bem-estar das pessoas. Ao mesmo tempo, a sociedade foi se tornando cada vez mais pluralista e caracterizada pelo respeito à diversidade, mesmo nas questões mais fundamentais. Esse foi o background das transformações sobre o aborto ${ }^{46}$.

Em 1886, a Holanda aprovou uma lei que criminalizou o aborto. No entanto, a lei era de difícil aplicação porque não se conseguia determinar se o feto estava vivo no momento do crime, o que era exigido para se configurar a tipificação legal. Nos anos 1970, houve diversas tentativas de abolição completa do crime. Em 1981, o país aprovou uma lei liberalizando o aborto, permitindo às mulheres abortarem até as 13 semanas de gravidez. Uma espera de cinco dias entre a consulta inicial e o aborto é exigida, para que a mulher tenha tempo de repensar e decidir se realmente deseja fazer o aborto. Apesar da legalização, a Holanda tem um dos menores índices de aborto no mundo. Entre 1977 e 1990, o aborto atingia a média de 5.1 a 6.5 para cada mil mulheres nas idades de 15 a 44 anos $^{47}$.

O distanciamento entre Igreja e Estado na Holanda, que continua sendo mantida até os dias atuais apesar da forte e constante pressão de grupos religiosos, influencia diretamente na legislação mais permissiva do mundo sobre os domínios recalcitrantes. A Holanda tem sido um país que resiste a essas influências religiosas e morais, mantendo-as longe da discussão legislativa, diversamente do que ocorre nos países cujas decisões passa-se a estudar a seguir.

O ABORTO DO ANENCÉFALO NOS ESTADOS UNIDOS DA AMÉRICA: CASO BRITELL V. ESTADOS UNIDOS DA AMÉRICA

Breves Considerações sobre as Particularidades Locais Relacionadas ao Aborto:

Nos Estados Unidos, o tema do aborto é extremamente tormentoso, talvez mais do que em qualquer outro país, porque se vive o paradoxo de ser

\footnotetext{
${ }^{45}$ BEER, Joop de; DEVEN, Freddy. Diversity in Family Formation: the 2nd demographic transition in Belgium and the Netherlands., Springer; 1st edition (October 15, 2000), p. 25.

${ }^{46}$ COLE, George D. FRANKOWSKI, Stanislaw. Abortion and Protection of the Human Fetus: legal problems in a cross-cultural perspective (Current and Legal Issues in International and Comparativ). University of Santa Clara. Institute of International and Comparative, 1987, p. 167.

${ }^{47}$ SIMON, Rita James. A comparative perspective on major social problems. Lexington Books, 2001, p. 189.
} 
um dos países mais modernos e mais religiosos do ocidente e essa religiosidade que beira o fundamentalismo ${ }^{48}$ tem que conviver com a força dos movimentos feministas progressivos, que são mais poderosos nos Estados Unidos do que em qualquer outro local do mundo ${ }^{49}$.

Vive-se, naquele país, a realidade dialética de uma nação que, apesar de ter se estabelecido em princípios fortes de separação entre igreja e estado, pois a primeira emenda estabelece os princípios da neutralidade e da separação recíproca entre a Igreja e o estado, mas por outro lado se permite que as esferas religiosa e a política continuem a se mesclar ${ }^{50}$. John F. Kennedy foi o primeiro presidente católico dos Estados Unidos e, desde o seu discurso inaugural, comprometeu-se a fazer a vontade de Deus, afirmando: "nesta terra, a obra de Deus realmente está acontecendo através de nossas mãos" 51 .

Nos Estados Unidos, mais do que dar à via política um fundamento moral, a religião civil sempre teve uma função de unificação, patriótica e semântica na construção da comunidade nacional, sendo constitutiva de uma expressão autêntica da identidade nacional e mostrando-se reiteradamente como determinante na eleição de agentes públicos dos três poderes.

Especialmente após o caso Roe versus Wade $^{52}$, as plataformas presidenciais republicanas reivindicaram uma emenda que proibisse completamente o aborto, exigindo ainda a nomeação de juízes que respeitasse os valores familiares tradicionais e a santidade da vida humana. Os presidentes Reagan e Bush, que foram eleitos dentre outros fatores sob essa promessa, impuseram essa característica às nomeações judiciais ${ }^{53}$, tanto para a Suprema Corte quanto para os tribunais inferiores.

Assim, é clarividente que as grandes batalhas acerca do aborto nos Estados Unidos têm um pano de fundo nitidamente fincado no valor intrínseco

${ }^{48}$ HOFFMANN, John P., and Sherrie Mills Johnson. 2005. Attitudes Toward Abortion Among Religious Traditions in the United States: Change or Continuity? Sociology of Religion $66, \mathrm{n}^{\circ} 2$ : 161-182. Academic Search Complete, EBSCOhost (accessed November 9, 2010).

49 DWORKIN, Ronald. Domínio da Vida: aborto, eutanásia e liberdades individuais. São Paulo: Matins Fontes, 2009, p. 5.

50 RANDAXHE, Fabienne. 2007. Religion, Politique et Régulation Juridique aux États-Unis. French Politics, Culture \& Society 25, $\mathrm{n}^{\circ} 3:$ 19-36. Academic Search Complete, EBSCOhost (accessed November 9, 2010).

${ }^{51}$ BELLAH, Robert Neelly. Civil Religion in America. Journal of the American Academy of Arts and Sciences 96 (1): 1-21. Disponível em http://www.robertbellah.com/articles_5.htm. Acesso em 30 nov. 2010.

52 Trata-se de um famoso caso julgado pela Suprema Corte em 1973, no qual se declarou inconstitucional qualquer lei estadual que proibisse o aborto para proteger a vida do feto nos dois primeiros trimestres de gravidez. Com essa decisão, houve alteração nas leis de quase todos os cinqüenta estados norte americanos, o que fez a disputa entre os grupos pró e contra o aborto ficar extremamente acirrada.

${ }^{53}$ DWORKIN, Ronald. Domínio da Vida: aborto, eutanásia e liberdades individuais. São Paulo: Matins Fontes, 2009, p. 8. 
e cósmico da vida humana, com uma natureza religiosa e essa natureza influencia não somente no processo de tomada de decisões, mas no processo de escolha dos agentes públicos, de maneira que é evidente que esse tema é um domínio recalcitrante naquele país e, por isso, qualquer tentativa de imposição seria fadada ao fracasso.

\section{Legislação Local sobre o Aborto:}

O aborto é legal, desde os anos 70, na esmagadora maioria dos estados, só não é legal no Dakota do Sul. O fator religioso, no entanto, exerce uma tamanha influência que quase todos os estados americanos, com exceção de Alabama, New Hampshire e Vermont, aprovaram leis de objeção de consciência, pelas quais os profissionais da saúde podem alegar razões religiosas para recusar tratamento a uma paciente que esteja sofrendo de hemorragia porque realizou um aborto. Se a paciente morrer a objeção de consciência não será considerada crime ${ }^{54}$.

O aborto é permitido nos Estados Unidos desde 1973, quando a Suprema Corte reconheceu que o aborto é um direito garantido pela Constituição americana. Não há uma lei sobre o tema, mas apenas esse precedente que, por se tratar de um país do common law, tem força praticamente normativa.

\section{Estudo do Caso:}

O primeiro caso é a demanda BRITELL v. UNITED STATES ${ }^{55}$. Britell descobriu em uma ultrasonografia de 20 semanas de gravidez que esperava um filho com anencefalia, tendo o diagnóstico sido confirmado por um segundo exame ultrasom. Britell e seu esposo resolveram abortar o feto anencéfalo, o que fizeram em 18.02.1994, no New England Medical Center. Após o procedimento, comprovou-se o diagnóstico de anencefalia. Algum tempo após, Britell foi acionada para pagar as despesas médicas, considerando que aquele aborto não era previsto nas hipóteses legais e assim iniciou-se a disputa judicial.

Britell alegava que sua situação era diferente dos precedentes anteriores em que se proibia o uso de recursos públicos federais em casos de aborto, salvo quando a vida da mãe estivesse em risco. Afirmou ela que seria inconstitucional aplicar esse precedente ao seu caso, pois o aborto em caso de anencefalia envolvia uma situação em que não haveria interesse legítimo do Estado na proteção da vida do feto. O governo respondeu argumentando que o financiamento estatal ao aborto de Britell encorajaria outros abortos e que isso estaria racionalmente relacionado ao legítimo interesse estatal na vida humana potencial.

\footnotetext{
${ }^{54} \mathrm{http}: / / \mathrm{www}$. consciencelaws.org/laws/usa/law-usa-02.html.

${ }^{55}$ United States Court of Appeals, Federal Circuit, 2004. Maureen M. BRITELL, Plaintiff-Appellee, v. UNITED STATES, Defendant-Appellant. Disponível em: http://caselaw.findlaw.com/summary/ opinion/us-federal-circuit/2004/06/24/124040.html, acesso em 03 jul. 2010.
} 
Britell argumentou ainda que duas distinções seriam necessárias em relação ao precedente anterior, sob pena de inconstitucionalidade: (1) a distinção mais ampla entre serviços médicos necessários durante a gravidez e o aborto médico necessário em caso de feto anencéfalo e (2) a distinção mais estreita entre interrupção de gravidez ectópica ou o tratamento de abortos espontâneos (financiados) e os abortos dos fetos anencéfalos (não financiados). Em contrapartida, o governo sugeriu a fixação de objetivos governamentais legítimos: (1) a proteção e promoção da vida humana em potencial; (2) a criação de uma regra segunda a qual nenhum defeito de nascimento justificaria o uso de fundos federais para o aborto e (3) a comodidade dos contribuintes, que são forte e sinceramente opostos ao aborto, por intermédio do não uso dos recursos públicos em abortos.

No julgamento pela Corte Distrital, ficou assentado que quando o feto sofre de uma condição que lhe garante a morte iminente e nenhuma esperança de consciência ou funcionabilidade, não faria sentido manter a gravidez ou encorajar a mulher a levar a gravidez adiante para proteger uma "vida potencial". No entanto, a Corte de Apelação dos Estados Unidos entendeu que o feto com anencefalia não morre necessariamente no nascimento. Além disso, afirmou-se que embora seja certo asseverar que o Estado não tem legítimo interesse na vida potencial humana em casos de anomalia letal, a anencefalia não se iguala a essa condição.

Segundo a Suprema Corte, desde o início da gravidez, o Estado tem legítimo interesse na vida em potencial (Casey, 505 U.S. at 846, 112 S.Ct. 2791). Segundo a decisão, desde os primeiros estágios da gravidez, o Estado deve desenvolver regras e regulamentos para encorajar a mulher a saber que há argumentos filosóficos e sociais de grande peso para que ela continue com a gravidez até o final. Delineou-se que não há sentido em entender que o Estado tenha interesse em proteger a vida humana potencial apenas em caso de viabilidade. Pelo contrário, o Estado tem interesse legítimo na vida humana potencial antes mesmo que alguém descubra se o feto alcançaria a viabilidade, e o interesse estatal legítimo existe mesmo quando o feto é diagnosticado com uma anormalidade ou defeito de nascimento, situação à qual a Corte equiparou a anencefalia, distinguindo-a da letalidade.

Afirmou-se que, para acatar o argumento de Britell no sentido de que em algumas circunstâncias o defeito de nascimento ou anormalidade fetal são tão severos a ponto de remover o interesse estatal na vida humana em potencial seria necessário que a corte estabelecesse uma linha divisória com base em fatores não judiciais, o que eles se recusaram a fazer. A Corte concordou então com o argumento governamental de que fazer isso poderia criar um risco muito grande. Confira-se:

"We agree with the government's argument that the type of line-drawing urged by Britell can create a slippery slope. It is not the role of the courts to draw lines as to which fetal abnormalities or birth defects are 
so severe as to negate the state's otherwise legitimate interest in the fetus' potential life. ... No reason has been presented, nor do we see one, to explain why consciousness (or extended life span) is the lynchpin of potential human life. Indeed, it could reasonably be argued that other birth defects or abnormalities, while different in their effects on the fetus, are also so severe as to negate the state's interest in potential human life. If that is the case, courts will be forced to determine on a condition-by-condition or abnormality-by-abnormality basis whether a fetus' condition is so severe as to eliminate the state's interest. Such line-drawing is something for which courts are ill-equipped, and is inconsistent with existing Supreme Court jurisprudence on what constitutes a "potential human life."

Em conclusão, o primeiro julgamento foi revertido sob o argumento de que, embora a Corte e certamente toda a humanidade ${ }^{56}$ sentissem grande simpatia por pais que recebem o terrível diagnóstico da anencefalia fetal, a lei é clara e o Estado tem o legítimo interesse na vida potencial humana desde o início da gravidez da mulher, independente de um diagnóstico de severo defeito de nascimento ou anormalidade fetal.

Verifica-se, nessa decisão, que o argumento de que o Estado tem legítimo interesse na proteção da vida humana, ainda no caso de anencefalia, na realidade mascara um valor subjacente, de natureza moral e quiçá religioso, assim fugindo do argumento central do caso, que era o direito da mãe em interromper a gravidez do feto anencéfalo exatamente por causa dessa inviabilidade. $O$ argumento da proteção da vida humana remonta ao valor religioso da sacralidade da vida, e se constitui em um argumento de autoridade que dificulta o posicionamento contrário e, por outro lado, faz com que o julgador consiga esconder os reais fatores que 0 levaram a tomar aquela posição. Tanto assim que o argumento governamental de que não seria justo que os contribuintes pagassem pelo aborto quando a maioria deles é contra o aborto foi acatado pela Suprema Corte.

Não se duvida que o Estado tenha legítimo interesse na proteção da vida humana, mas esse interesse não poderia ser mitigado para dar prevalência ao interesse da gestante, já que há uma inviabilidade da vida do feto anencéfalo? Esse era o argumento central de Britell, que não foi respondido pela Corte, sob a proteção do manto da sacralidade da vida, escondido sob o argumento de autoridade do legítimo interesse do Estado

\footnotetext{
56 "Although this court, and surely all humankind, feels great sympathy for any parent faced with the truly horrifying diagnosis of anencephaly, we find that the law is clear: the state has a legitimate interest in potential human life from the outset of a woman's pregnancy, regardless of a diagnosis of a severe birth defect or fetal abnormality. Because, by analogy to McRae, the language of section 1093(a) is rationally related to this legitimate state interest, section 1093(a), just as the Hyde Amendment to Medicaid, passes rational basis review. The language of the two bans on funding is virtually identical, and the differences, for constitutional rational basis review, between Medicaid and CHAMPUS are insignificant. Accordingly, the district court's entry of judgment for Britell, must be REVERSED".
}

DiReITOS FundAMENTAIS E J JUSTIÇA - AN0 5, N 16, P. 95-135, JUL./SET. 2011 
na proteção da vida humana. O argumento de que a Corte não poderia distinguir caso a caso quando uma anomalia fetal fosse tão severa a ponto de afastar o legítimo interesse do Estado em proteger a vida humana em potencial, pois isso seria uma tomada de decisão com base em fatores não judiciais é, no mínimo, covarde, pois não se pode negar a prestação jurisdicional apenas porque a demanda envolve questões não jurídicas.

O ABORTO DO ANENCÉFALO NA ARGENTINA: CASO SILVIA TANUS V. GOVERNO DE BUENOS AIRES

Breves Considerações sobre as Particularidades Locais Relacionadas ao Aborto:

$\mathrm{Na}$ Argentina, há mais de vinte anos diversos projetos de lei foram apresentados no parlamento, visando uma reforma legal para despenalizar o aborto, mas os legisladores, com receio da repercussão política, tem evitado a discussão. Exemplo da forte pressão da Igreja católica sobre o parlamento argentino é o fato de que há mais de cinco anos está pendente no Congresso Nacional a ratificação do Protocolo Facultativo da Convenção sobre a eliminação de todas as formas de discriminação contra a mulher, sob o receio de isso configurar uma abertura de portas para a discriminação do aborto.

O ex-presidente argentino Carlos Menem manteve uma postura radicalmente contra o aborto, tendo feito, em 1998, uma visita ao Vaticano e encontrado o então Papa João Paulo II, ocasião em que se comprometeu publicamente com a defesa da vida, a qual considerou como prioridade da Argentina e de sua política externa, manifestando-se então contra o aborto e afirmando a proteção às "crianças por nascer" 57 .

Depois que o Presidente Menem deixou o cargo em 1999, o clima político mudou. Menem, como visto, era religioso e extremamente contrário ao aborto. Em seguida, Fernando la Rúa (1999-2001), embora ainda se opusesse ao aborto, assumiu uma política um pouco mais neutra e passou a assumir internacionalmente que os direitos reprodutivos das mulheres e os direitos sexuais fazem parte dos direitos humanos e reconheceu a conexão entre as taxas de aborto e a falta de acesso das mulheres aos serviços de saúde. Em seu discurso perante as Nações Unidas em junho de 2000, o Ministro das Relações Internacionais, Enrique Candioti, fez essa declaração de forma

\footnotetext{
${ }^{57}$ MENEM, Carlos. Discurso del Presidente Menem en el acto en conmemoración del "Día Nacional del Niño por Nacer", Decreto 1406/98, realizado en el Teatro Coliseo, disponível em <http://www.vidahumana.org/dia/discurso.html>, acesso em 11 fev. 2010: "Creo que ha llegado el momento en que quienes defendemos la vida debemos hacer algo más que reaccionar ante algunas manifestaciones contrarias a la dignidad de la persona humana. Debemos además, salir al mundo a proclamar sin temor la condición de ser humano que tienen los niños por nacer, a crear en los hombres y en las naciones la convicción de que la vida no debe quitarse a nadie y menos aún, a los más débiles e indefensos. Debemos, en definitiva, convertirnos en heraldos de la cultura de la vida. Por ello, es mi aspiración que esta iniciativa que hoy presentamos para honrar a los niños por nacer, pueda ser adoptada para un gran número de naciones".
} 
expressa, em uma postura que se aparta bastante daquela sustentada pelo governo anterior ${ }^{58}$.

O Presidente Néstor Kirchner (eleito em 2003) professava a fé católica, mas é considerado mais progressista do que seus antecessores. Em 2005, a ministra da Saúde Ginés González García declarou publicamente seu apoio à legalização do aborto e o presidente se manteve neutro quanto à postura de sua ministra.

Em maio de 2006 o governo tornou público um projeto de reforma do Código Penal, que inclui a descriminalização do aborto, o qual ainda está em discussão e não foi formalmente inserido na pauta legislativa, mas sugere uma maior abertura da Argentina ao tema. Há uma forte luta de cerca de 250 organizações sociais argentinas de mulheres que lançou uma campanha nacional pelo direito ao aborto legal, seguro e gratuito ${ }^{59}$, com o lema "Educação sexual para decidir, anticoncepcionais para não abortar, aborto legal para não morrer",coletando assinaturas e tentando sensibilizar a sociedade sobre a necessidade de debater o tema, até mesmo em face ao alarmante número de que $40 \%$ das gestações na Argentina terminam em abortos clandestinos e que o aborto clandestino ocupa o primeiro lugar das causas de morte materna ${ }^{60}$.

\section{Legislação Local sobre o Aborto:}

O aborto na Argentina é estritamente limitado pela lei. O Código Penal Argentino estabelece sanções para as mulheres que praticam o aborto, assim como estabelece punições para os médicos e outros agentes da saúde que os realizam. O aborto é considerado não punível nas seguintes circunstâncias: (1) se for realizado a fim de evitar danos para a vida da mulher ou de saúde, desde que não existem outros meios de evitar tais danos; (2) se a gravidez foi resultado de estupro de uma mulher mentalmente incapaz.

Verifica-se, portanto, que assim como ocorre no caso da legislação brasileira, em que o art. 128 do Código Penal deixa margem à discussões quando se insere o caso do feto anencéfalo, no caso da legislação argentina a mesma lacuna é percebida, pois a expressão evitar danos à saúde pode ser interpretada também como dano à saúde mental da mulher, interpretação que possibilitaria inserir a antecipação do feto anencéfalo em uma das ressalvas de punibilidade.

\footnotetext{
${ }^{58}$ HTUN, Mala. Abortion Politics and Policy in Argentina, Brazil, and Chile. Conference Papers -American Political Science Association (August 28, 2002): 1-47. Academic Search Complete, EBSCOhost (accessed November 9, 2010).

${ }^{59}$ CARBAJAL, Mariana. La Situación del Aborto en la Argentina. Un debate pendiente. Debate Feminista 34, $\mathrm{n}^{\circ} 17$ (October 2006): 143-157. Academic Search Complete, EBSCOhost (accessed November 9, 2010).

${ }^{60}$ Estadísticas Vitales. Información Básica. Año 2004, disponível em http://web.ebscohost.com/ehost/ pdfviewer/pdfviewer?vid=20\&hid=112\&sid=9bb3f265-13e9-9eb-b648-893cc9f763d9\%40sessionmgr110, acesso em 09 nov. 2010.
} 


\section{Estudo do Caso:}

O segundo caso a ser analisado é da Corte Suprema da Argentina, Silvia Tanus c/ Gobierno de la Ciudad Autónoma de Buenos Aires s/Amparo. Silvia Tanus e seu marido, após receberem o diagnóstico da anencefalia, em 2001, solicitaram intervenção médica para interromper a gravidez, a qual foi negada ao argumento de que o caso não se inseria em uma das possibilidades de aborto, segundo o Código Penal, como acima visto. A mãe recorreu à justiça local, que em primeira e segunda instância negou o direito ao aborto, com fundamento no respeito à vida do nascituro. O Tribunal Superior da Cidade Autônoma de Buenos Aires, por maioria de votos (quatro a um), ao julgar o recurso, autorizou a interrupção da gravidez, mas o Defensor de Menores interpôs recurso extraordinário na Corte Suprema, sob o fundamento de que a indução do parto afetava a vida do nascituro. A Corte Suprema autorizou a indução do parto, quando a mãe já estava no oitavo mês de gravidez, determinando ao hospital materno infantil Ramón Sardá que procedesse à intervenção, impondo ainda ao hospital a obrigação de informar o resultado da intervenção médica em 24 horas.

A Corte considerou que o valor defendido pelo Defensor de menores, ou seja, a vida humana, não poderia ser medido, eis que nenhuma vida humana haveria a se proteger, por ser certa a imediata morte depois do parto, cientificamente considerada como inevitável, de forma que adiantar ou postergar tal fato não beneficiaria nem prejudicaria a sorte do nascituro. Considerou-se ainda que a frágil e incerta vida uterina do nascituro coexiste com o sofrimento psicológico da mãe e de sua família, progressivamente deteriorada em sua convivência em função do acontecimento dramático e inevitável. Considerou-se ainda que a proteção à vida desde a concepção só se evidencia quando o feto pode sobreviver de forma autônoma, de forma que a decisão estaria em plena consonância com a Convenção dos Direitos da Criança, aprovada na Argentina pela Lei $n^{\circ} 23.849$ (artigo $2^{\circ}$ ) e com a Convenção Americana dos Direitos Humanos. Por fim, afirmou-se não se tratar de um caso de aborto, nem de aborto eugenésico, nem de eutanásia, que pudesse excluir a proteção da vida, pois a carência de cérebro produziria, ante um parto normal, a imediata incapacidade do feto em subsistir. Confira-se:

"Que debe exponerse, como resumen de lo aquí señalado, que no trata de un caso de aborto, ni de aborto eugenéstico, ni de una suerte de eutanasia, ni de un ser que no es -para excluir la protección de su vidapersona, ni de la libertad de procreación para fundar la interrupción de su vida.

En efecto, tales acciones aparecen identificadas con una acción humana enderezada a provocar la muerte del niño durante su gestación.

Por el contrario, lo que aquí se autoriza es la inducción de un nacimiento una vez llegado el momento en que el avance del embarazo asegura - 
dentro del margen de toda situación vital- el alumbramiento de un niño con plenas posibilidades de desarrollarse y vivir.

No sólo ello: entre las cargas impuestas a los médicos que intervendrán, se les señala que deberán cumplir todas las reglas del arte de la medicina "con el mayor respeto hacia la vida embrionaria".

Esta es una decisión con pleno respeto a la vida desde el momento de la concepción, con gestación de plazo suficiente -que comienza el curso del octavo mes o trigésima segunda semana-, cuyo resultado no depende de la acción humana, sino de la trágica condición de este niño por nacer: su carencia de cerebro producirá, ante un parto normal, su casi inmediata incapacidad de subsistir, debido a la ausencia de los medios fisiológicos mínimos para la actuación de sus funciones vitales". ${ }^{61}$

Clinicamente falando, aborto é a interrupção de qualquer gravidez antes da vigésima oitava semana, de forma que, tanto se a interrupção da gravidez for de um feto anencéfalo ou não, haveria aborto e, portanto, no caso sob o crivo da corte Argentina, tratava-se, sim, de aborto. Mas, como o termo é dotado de um forte sentido pejorativo, quer por ser crime como por ser pecado, preferiu-se evitá-lo. A decisão foi dotada de uma carga tão alta de emotivismo que se falou que, no caso do anencéfalo, o nascimento poderia ser conceituado como um "cruzar o umbral que, na espécie, resta insuperável porque o mero ato da travessia provoca a morte". E acrescentou-se que, dessa suprema contradição entre vida e morte fluem os sentimentos confusos que o caso guarda.

A utilização dos tratados como foi feito no caso argentino, longe de constituir um diálogo de juízes ${ }^{62}$, representou uma utilização desses instrumentos de forma a legitimar a decisão tomada com base em fatores religiosos e morais. Tanto assim que, embora citando tais documentos, a Corte Argentina os interpretou de forma tendenciosa à visão da demandante, afirmando que a frágil e incerta vida intra-uterina do nascituro, com o sofrimento psicológico de sua mãe e de sua família inteira, que vê progressivamente deteriorada sua convivência em função de um acontecimento dramático, que se estende e se agrava e, para embasar essa conclusão, distanciou-se da discussão do aborto e apoiou-se a Corte em um laudo psicológico sobre o sofrimento da gestante ${ }^{63}$.

Segundo Martha Nussbaum, a emoção não vive apartada dos julgamentos públicos. Discute-se perdão e compaixão, especialmente em casos penais,

${ }^{61}$ Disponível em www.notivida.com.ar/../CSJN,\%20Caso\%20Sivia\%20Tanus.html, acesso em 30 jul. 2010.

62 DELMAS-MARTY, Mireille. Les Forces Imaginantes du Droit (II). Le Pluralisme Ordonné. Éditions du Seuil, 2006, p. 25.

${ }^{63}$ Que, en esas condiciones, coexiste la frágil e incierta vida intrauterina del nasciturus, con el sufrimiento psicológico de su madre y de su familia entera, que ve progresivamente deteriorada su convivencia en función de un acontecimiento dramático, que se extiende y agrava si dar margen para la elaboración del duelo (ver informe psicológico de fs. 12/14, valorado con las limitaciones que se expresar en la sentencia recurrida). 
sob o manto do discurso racional ${ }^{64}$, é o que se verifica claramente no caso acima analisado, pois a compaixão pela mãe falou mais alto do que qualquer documento jurídico nacional ou internacional sobre o tema do aborto do feto anencéfalo e houve, na Corte Argentina, espaço para que essa decisão fosse tomada, por causa do clima político vivido à época, com uma maior abertura à prevalência dos direitos reprodutivos e sexuais da mulher.

\section{O ABORTO DO ANENCÉFALO NO BRASIL}

\section{ao Aborto:}

Breves Considerações sobre as Particularidades Locais Relacionadas

No Brasil, a pressão religiosa pela não descriminalização do aborto tem tido uma força impressionante. Recentemente, aliás, o tema chegou a influenciar no processo eleitoral, pois com a afirmação de que a então candidata Dilma Roussef seria a favor da legalização do aborto, grupos religiosos passaram a pedir que os fiéis não votassem nela ${ }^{65}$ e o seu adversário, José Serra, explorou arduamente esse fato na campanha, posicionando-se expressamente contra o aborto.

Anteriormente, em 18 de novembro de 2007, a 13a Conferência Nacional da Saúde ocorrida em Brasília, rejeitou a proposta de legalização do aborto, o que também já tinha ocorrido na $12^{\mathrm{a}}$ Conferência Nacional da Saúde, realizada em 2003.

Em 7 de maio 2008, após um longo período de discussões, o Projeto de Lei 1.135/91, que previa a extinção dos artigos do Código Penal que criminalizam o aborto praticado com consentimento da gestante, foi rejeitado por unanimidade na Comissão de Seguridade Social e Família da Câmara dos Deputados, com o acompanhamento e pressão forte de grupos religiosos.

Por outro lado, em 19 de maio de 2010, foi aprovado pela Comissão de Seguridade Social e Família da Câmara dos Deputados o Estatuto do Nascituro, que visa proibir o aborto em todas as circunstâncias, afastando inclusive os casos de aborto sentimental. A organização não governamental "Brasil sem Aborto" tem em seu quadro 185 parlamentares que são favoráveis à "defesa da vida desde a concepção", e concentra forças em impedir o progresso de qualquer projeto legislativo que vise descriminalizar o aborto:

\footnotetext{
${ }^{64}$ NUSSBAUM, Martha C. Poetic Justice. The Literary Imagination and Public Life. Beacon Press Books, 1995, pgs. XIV e XV.

65 "A notícia teve origem pela decisão corajosa do bispo de Guarulhos, d. Luiz Gonzaga Bergonzini, que pregará voto consciente contra Dilma Rousseff em missas de 37 paróquias da cidade, um dos principais redutos do PT paulista. Ele considera o partido favorável à descriminalização do aborto. "Recomendamos a todos verdadeiros católicos que não deem seu voto à senhora Dilma Rousseff e demais candidatos que aprovam tais liberações", diz artigo assinado pelo bispo e divulgado pela diocese. D. Luiz Gonzaga evoca deliberações de congressos petistas e o $3^{\circ}$ Programa Nacional de Direitos Humanos e classifica o PT como contrário aos valores da família e à liberdade de expressão". Disponível em <http://www.domtotal.com/noticias/detalhes.php?notld=235133>. Acesso em 11 fev. 2011.
} 
A Câmara dos Deputados teve uma renovação de $46 \%$ e isso representa 235 novos deputados e deputadas. A primeira grande tarefa da Frente Parlamentar em Defesa da Vida - Contra o Aborto será a de verificar o percentual de parlamentares que são contra a legalização do aborto no Congresso Nacional. Isso será feito, segundo o Presidente da Frente Parlamentar em Defesa da Vida, Deputado Federal Luiz BassumaPT/BA, reeleito, "com a máxima urgência", uma vez que, faz-se necessário recompor a Frente Parlamentar para continuar a realizar o seu trabalho de articulação política dentro do Congresso Nacional, com o objetivo de barrar toda e qualquer proposição legislativa que tenha como escopo legalizar ou descriminalizar o aborto em nosso país ${ }^{66}$.

Percebe-se, portanto, a tênue linha que separa (ou não separa) os dogmas cristãos e o exercício da política, embora pela Constituição brasileira o Estado seja laico. Vê-se, portanto, a clara influência da Igreja na política brasileira e a dificuldade de sucesso de qualquer proposição legislativa que pretenda a descriminalização do aborto no país, o que é feito antes mesmo da eleição dos nossos representantes, como se viu anteriormente.

\section{Legislação Local sobre o Aborto:}

No Brasil, o Código Penal tipifica o aborto como crime, segundo o art. 124 e seguintes, permitindo-se todavia a prática em excepcionais circunstâncias, quais sejam: (1) quando não há outro meio para salvar a vida da mãe; (2) quando a gravidez resulta de estupro.

No Código Civil, art. $2^{\circ}$, há a previsão da proteção jurídica aos direitos do nascituro desde a concepção e no Estatuto da Criança e do Adolescente, art. $7^{\circ}$, prevê-se que o nascituro tem o direito à vida, mediante a efetivação de políticas públicas que permitam o nascimento. Em 25 de setembro de 1992, o Brasil ratificou a Convenção Americana de Direitos Humanos, que dispõe, em seu artigo $4^{\circ}$, que o direito à vida deve ser protegido desde a concepção. A Constituição Federal, de forma mais genérica, prevê o direito à vida no art. $5^{\circ}$, caput.

A par dessa previsão legislativa, é ampla a discussão doutrinária sobre a tipicidade ou não da antecipação do parto do feto anencéfalo. Há quem entenda que o Código Penal, por ser da década de 40, não se adéqua à realidade atual da ciência, que permite detectar, ainda no útero da gestante, anomalias letais como seria o caso da anencefalia e que a dor da gestante, nessa situação, seria equiparável à aflição derivada da gestação da mulher estuprada e que, por isso, a anencefalia deveria ser considerada causa supralegal de exclusão da ilicitude ${ }^{67}$. Há ainda quem entenda que, com base

${ }^{66}$ LOPES, Jaime Ferreira. Frente contrária ao aborto leva vantagem. Brasil sem aborto. Disponível em http://www. brasilsemaborto.com.br/destaques. asp?op=1\&id=147. Acessado em 02 fev. 2011.

67 BUSATO, Paulo César. Tipicidade Material, Aborto e Anencefalia. Disponível em <http://www2.mp.ma.gov.br/ampem/artigos/25.\%20Anencefalia_e_\%20aborto.pdf>. Acesso em 10 fev. 2011.

DiReITOS FundaMentals E E JUSTIÇA - ANO 5, N 16, P. 95-135, JUL./SET. 2011 
na teoria da imputação objetiva, o aborto do feto anencéfalo, à luz da legislação vigente, seria um fato atípico, porque não haveria uma situação de risco proibido, mas sim de risco permitido ${ }^{68}$, dentre outras teses.

\section{Estudo do Caso:}

Em julho de 2004, no processo da ação de descumprimento de preceito fundamental $n^{\circ} 54 / 2004$, o Ministro Marco Aurélio de Mello, do Supremo Tribunal Federal, concedeu liminar autorizando a interrupção da gravidez nos casos de anencefalia. Todavia, esta decisão foi revogada em 20 de outubro do mesmo ano pelo plenário do Tribunal. Até hoje, contudo, ainda não foi julgado o processo.

O Supremo Tribunal Federal assentou a adequação da argüição de descumprimento de preceito fundamental ajuizada pela Confederação Nacional dos Trabalhadores na Saúde - CNTS, na qual se pretende obter posicionamento do tribunal sobre o aborto de feto anencéfalo. A CNTS aponta como violados os preceitos dos artigos $1^{\circ}$, IV (dignidade da pessoa humana); 50 II (princípio da legalidade, liberdade e autonomia da vontade); $6^{\circ}$, caput, e 196 (direito à saúde), todos da Constituição Federal, e, como ato do Poder Público, causador da lesão, o conjunto normativo ensejado pelos artigos 124, 126, caput, e 128, I e II, do Código Penal, requerendo, em última análise, a interpretação conforme à Constituição dos referidos dispositivos do Código Penal, a fim de explicitar que os mesmos não se aplicam aos casos de aborto de feto anencéfalo.

O relator entendeu que os requisitos concernentes à ação foram devidamente atendidos (Lei 9.882/99, arts. $1^{\circ}, 3^{\circ}$ e $4^{\circ}, \S 1^{\circ}$ ) e salientou a presença de argumentos em torno de valores básicos inafastáveis no Estado Democrático de Direito e, de outro lado, os enfoques do judiciário com arrimo em conclusões sobre o alcance dos dispositivos do Código Penal que dispõem sobre o crime de aborto, concluindo pela necessidade do pronunciamento do Tribunal, a fim de se evitar a insegurança jurídica decorrente de decisões judiciais discrepantes acerca da matéria.

Assentou-se a inexistência de outro meio eficaz de sanar a lesividade alegada, apontando-se, como fundamento, o que verificado relativamente ao habeas corpus 84025/RJ (DJU de 25.06.2004), da relatoria do Min. Joaquim Barbosa, no qual a paciente, não obstante recorrer a essa via processual, antes do pronunciamento definitivo pela Corte, dera à luz a feto que veio a óbito em minutos, ocasionando o prejuízo da impetração.

Em julho de 2004, o Min. Marco Aurélio de Mello, do Supremo Tribunal Federal, deferiu medida liminar autorizando a interrupção da gravidez nos casos de anencefalia. Baseou-se para tanto nos princípios constitucionais da liberdade e preservação da autonomia da vontade, da legalidade, do direito

\footnotetext{
${ }^{68}$ GOMES, Luiz Flávio. Teoria da Imputação Objetiva e Aborto anencefálico: atipicidade material do fato. Disponível em <http://www.lfg.com.br/artigos/art_aborto_lfg.pdf>. Acesso em 10 fev. 2011.
} 
a saúde e da dignidade da pessoa humana ${ }^{69}$, decisão esta que foi revogada quando do julgamento de mérito da ação.

O debate é profundamente ético, repousa sobre questões religiosas e morais e, por isso, o relativismo deve se sobrepor ao universal, embora, no caso brasileiro, os fundamentos da decisão do Ministro Cezar Peluso, ao suspender a liminar que havia autorizado mulheres a interromperem a gestação de fetos anencéfalos, tenha pretendido escapar dessa análise. Afirmou o ministro:

[...] A integridade física e biológica da vida intra-uterina também está em jogo. Depois, o sofrimento em si não é alguma coisa que degrade a dignidade humana; é elemento inerente à vida humana. O remorso também é forma de sofrimento [...] Nem quero discorrer sobre o aspecto moral e ético - não me interessa - de como o sofrimento pode, em certas circunstâncias, até engrandecer pessoas [...]. ${ }^{70}$

O fundamento de que o sofrimento não degrada, mas sim é inerente à vida humana, de que o remorso também é uma forma de sofrimento e de que o sofrimento pode engrandecer pessoas não é jurídico, mas sim religioso. Segundo a Bíblia, não citada pelo Ministro, mas certamente norteadora de seu voto sem fundamento jurídico, "porque isto é agradável, que alguém, por causa da consciência para com Deus, suporte tristezas, padecendo injustamente" ${ }^{, 71}$. Vários salmos e provérbios falam do sofrimento dos justos e prega a aceitação do sofrimento.

Os principais argumentos utilizados no caso brasileiro para a contrariedade ou proibição do aborto do feto anencéfalo foram morais e com profundo amparo em valores cristãos a respeito do sentido da existência e do início da vida e é isso que se pretende desvendar, a fim de confirmar a hipótese antes mencionada, inspirada nos ensinamentos de Delmas-Marty, de que as zonas de resistência representadas pela religião e moral são obstáculos intransponíveis a um direito comum.

Em análise sobre os fundamentos religiosos como motivadores para as decisões acerca do aborto do feto anencéfalo no Brasil, Tamara Amoroso Gonçalves e Thais de Souza Lapa identificaram um total de sete acórdãos relacionados à anencefalia e má-formação que utilizavam de argumentos religiosos para fundamentação das decisões, em um universo de 52 analisados, correspondendo a 13,5\% destes, concluindo as autoras

\footnotetext{
${ }^{69}$ BRASIL. Supremo Tribunal Federal. Deferimento de pedido de medida cautelar. ADPF 54. Confederação Nacional dos Trabalhadores da Saúde. Relator: Marco Aurélio. 01 jul. 2004. Disponível em: http://gemini.stf.gov.br/cgibin/nphbrs?d=ADPF\&s1=anencefalia\&u= http://www.stf.gov.br/ Processos/adi/default.asp\&Sect1=IMAGE\&Sect2=THESOFF\&Sect3=PLURON\&Sect6=ADPFN\& $p=1 \& r=1 \& f=G \& n=\& l=20>$ Acesso em 05 jul. 2010.

${ }_{71}^{70}$ Cezar Peluso, 2004, p. 12

${ }^{71} 1$ Pedro 2:19
} 
que a defesa do direito à vida do feto de forma absoluta encontra-se intimamente ligada a uma influência religiosa, presente na argumentação dos magistrados ${ }^{72}$.

Pretende-se estender a pesquisa para o cenário universal, para comprovar a hipótese de que, tratando-se de tema que envolve valores religiosos e sentimentos ${ }^{73}$, depara-se com a dificuldade à fixação de valores ou princípios comuns.

Na decisão do STF, que terminou por proibir o aborto do feto anencéfalo, ADPF 54, diversos grupos religiosos pretenderam ingressar como amicus curiae, comprovando a forte mobilização da sociedade e especificamente desses grupos em temas que envolvem religião e moral.

Assim como o Brasil, cerca de outros cinqüenta países proíbem o aborto, havendo basicamente três opções legislativas quanto ao tratamento penal dado ao tema. Uma facção mais liberal é representadas por países como Japão, Rússia e Hungria, os quais conferem à mulher e ao médico uma maior liberdade de escolha e definição quanto ao aborto, assumindo o Estado, portanto, um papel menos ativo. Diversas razões, tais como o controle de natalidade, o interesse social, a prevalência da autonomia da vontade da mulher, laicidade do Estado, definem a política adota.

Uma facção intermediária é adotada na maior parte dos países, dentre eles o Brasil, que permite o aborto apenas em situações específicas e excepcionais previstas na lei. Os motivos permissivos do aborto são previstos em lei e variam de país para país. França e Suíça, por exemplo, admitem o aborto honroso.

Quanto à interrupção da gestação nos casos de anencefalia, em países como Áustria, Israel, Itália, Hungria, Suíça, República Tcheca, Nova Zelândia e Cuba, já se considera lícita. Essas legislações têm sua diferenciação estabelecida pelo tempo de gravidez e o grau de risco para a saúde e vida da mulher. França, Bélgica e Espanha são ainda mais liberais quanto ao aborto, pois consideram que para ser atribuída personalidade ao feto são necessárias a forma humana e a viabilidade. Países como Paraguai, México, Equador, Venezuela, Colômbia, Chile e China não admitem aborto em decorrência de má-formação fetal. ${ }^{74}$

A discussão pode ser colocada em termos de conflito de valores: os defensores do direito da gestante quanto à liberdade de escolha acerca do

\footnotetext{
72 GONÇALVES, Tamara Amoroso; LAPA, Thais de Souza. Aborto e Religião nos Tribunais Brasileiros. Coordenação de Tamara Amoroso Gonçalves. São Paulo: Instituto para a Promoção da Equidade, 2008, p. 195.

${ }^{73}$ NUSSBAUM, Martha C. Love's knowledge. Essays on philosophy and literature. New York: Oxford University Press, 1990, p. 267: "The Love is not some separate fact about us that is signaled by the impression; the impression reveal the love by constituting it".

${ }_{74}$ CARDIN, Valéria Silva Galdino. "DO ABORTO EUGÊNICO". Disponível em www.conpedi.org/manaus/arquivos/anais/brasilia/14_286.pdf, acesso em 05 jul. 2010.
} 
aborto acentuam que nos casos de anencefalia a gestação é incompatível em cem por cento dos casos com a vida extrauterina e, assim, não poderia gozar da mesma proteção constitucional e legal que uma vida viável. O direito deveria proteger, então, a saúde integral da mãe, física e emocionalmente, como valor prevalente ${ }^{75}$.

Há, por outro lado, os autores que defendem que a vida em gestação é um valor constitucional prevalente e que deve ser protegido desde a concepção, ainda quando não se pode dizer que há uma pessoa com direito à vida, ou seja, sem viabilidade, como é o caso do feto anencéfalo ${ }^{76}$.

DOS PROCESSOS DE INTERAÇÃO NO DIREITO INTERNACIONAL

Como visto nos casos acima estudados, os temas que envolvem os domínios recalcitrantes geram uma grande dificuldade de uniformização no direito internacional. Todavia, a uniformização é apenas uma das formas possíveis no processo de interação, quando se fala em internacionalização do direito. Coordenação por entrecruzamento, harmonização por aproximação e unificação por hibridação são possíveis formas de internacionalização do direito e precisam ser encaradas e estudadas, pois as situações de interdependência entre os Estados se multiplicam e o isolamento não é mais (se é que algum dia foi) possível. No específico caso estudado nesse trabalho, a existência do navio do aborto Women in waves demonstra a necessidade de uma internacionalização do direito em face da permeabilidade e porosidade do direito.

A primeira e mais radical forma de interação é a unificação dos sistemas jurídicos, que na realidade é uma negação de qualquer tipo de pluralismo e, embora pareça ser perfeita do ponto de vista formal, por permitir uma perfeita hierarquia e ordenação, ignora a noção de margem nacional e exclui completamente as possíveis diferenças. Dois são os mecanismos de unificação: transplantação e hibridação. Pela transplantação, simplesmente se transporta uma ordem jurídica de um país a outro, sem reciprocidade, privilegiando uma visão estática e soberana dos sistemas de direito $^{77}$. Já na unificação pela hibridação há um regime de reciprocidade, que em regra implica a modificação do direito nacional para adequar a legislação de mais um país.

A segunda modalidade de processo de interação é a coordenação por entrecruzamento, que se relaciona com a possibilidade de jogos de interpretação cruzados entre diversos órgãos, judiciários, jurisdicionais ou

${ }^{75}$ HOOFT, Pedro F. ANENCEFALIA: CONSIDERACIONES BIOÉTICAS Y JURÍDICAS. Acta bioética versión On-line ISSN 1726-569X, Acta bioeth. v.6 no 2 Santiago dic. 2000. Disponível em http://www.scielo.cl/scielo.php?pid=S1726-569X2000000200006\&script=sci_arttext, acesso em 05 jul. 2010.

${ }^{76}$ BIDART, G. Derecho Constitucional y Bioética en Relación con la Vida Humana. Revista Jurisprudencia Argentina 1998;6113 (Num. Esp.): 12-18.

77 DELMAS-MARTY, Mireille. Les Forces Imaginantes du Droit (II). Le Pluralisme Ordonné. Éditions du Seuil, 2006, p. 107. 
quase jurisdicionais, encarregados de aplicar as normas aos casos concretos ${ }^{78}$. A internormatividade cria uma dialética, mas não dá uma solução em caso de conflito e, por isso, surge a necessidade de interpretação. Ao mesmo tempo em que os juízes nacionais se internacionalizam, quer em razão da aplicação direta do direito internacional, quer em razão da extensão da competência nacional, os juízes internacionais se banalizam, à medida que suas competências parecem estar muito mais voltadas às questões privadas.

Com a coordenação por entrecruzamento, busca-se uma integração recíproca, por intermédio das trocas informais entre juízes para aproximar os pontos de vista e evitar conflitos jurisprudenciais pela via da informação recíproca, como se verificou que ocorreu no caso argentino e não ocorreu no caso brasileiro. O grande problema desse processo de interação é que ele não parece se adequar aos casos de conflitos extremos, casos em que os juízes são influenciados pela forte crença da população em um sentido ou em outro, como se verificou ter ocorrido no caso brasileiro sobre o aborto do feto anencéfalo. Aliás, esses temas, constantemente são determinantes até mesmo na escolha dos dirigente eleitos, como ocorreu nos Estados Unidos na eleição dos juízes da Suprema Corte e no Brasil, recentemente, na eleição presidencial.

Reconhece-se, portanto, que o entrecruzamento é necessário, mas não suficiente para evitar os conflitos. É necessário para minimizar os conflitos e reduzir as contradições, permitindo uma coordenação espontânea, mas não é suficiente para garantir a coerência do conjunto normativo, tanto assim que há quem afirme que esse processo de interação apenas prepara a transição dos diversos sistemas jurídicos ${ }^{79}$.

Alguns autores, ainda mais céticos, preferem afirmar que, mais do que assegurar a unidade do direito internacional, o importante é apenas assegurar a compatibilidade fraca entre os fragmentos ${ }^{80}$. No lugar de uma integração ilusória de uma sociedade global diferenciada, o direito poderia apenas, na melhor das hipóteses, um discreto civilizador de nações ${ }^{81}$, ou seja, não poderia evitar contradições entre as diferentes racionalidades sociais, mas poderia limitar danos.

O terceiro processo de interação é a harmonização por aproximação. Fala-se, então, em conceber a harmonização como uma alternativa à codificação, um processo novo que inclui o objetivo da integração normativa,

\footnotetext{
78 DELMAS-MARTY, Mireille. Les Forces Imaginantes du Droit (II). Le Pluralisme Ordonné. Éditions du Seuil, 2006, p. 41.

${ }^{79}$ DELMAS-MARTY, Mireille. Les Forces Imaginantes du Droit (II). Le Pluralisme Ordonné. Éditions du Seuil, 2006, p. 67.

80 TEUBNER, G. e FISCHER-LESCANO, A. Regime Collisions: the vain search for legal unity in the fragmentation of international law. In Michigan Journal of International Law, 2003/2004, p. 999-1046.

${ }^{81}$ KOSKENNIEMI, Martti. The Gentle Civilizer of Nations: The Rise and Fall of International Law. Cambridge: Cambridge University Press, 2001, p. 20.
} 
mas que se contenta com uma integração imperfeita, sem impor uma unificação, isto é, preservando as margens nacionais, mas permitindo a aplicação de princípios diretores comuns e viabilizando a cooperação jurídica entre os estados ${ }^{82}$.

A harmonização por aproximação é dada como exemplo exatamente para os casos em que a uniformização é impossível, como nos casos de diversidade moral e religiosa ${ }^{83}$, ou seja, casos em que tanto o isolamento quanto a codificação são impossíveis e que, portanto, a saída seria a busca dessa harmonização. A harmonização instaura uma relação vertical, ao contrário do entrecruzamento, que instaura apenas relações horizontais. Mas essa relação vertical instaurada pela harmonização seria do tipo hierarquia emaranhada ${ }^{84}$, significando a convivência de dinâmicas centrípetas, com primazia do direito supranacional e de dinâmicas centrífugas, com subsidiariedade do direito supranacional em prol do direito local.

A harmonização também é vista como um método de mútua acomodação e proteção dos direitos humanos, especialmente em casos de regimes diferentes, para que os tratados sobre direitos humanos possam ser implementados da melhor forma possível, de acordo com um princípio de harmonização ${ }^{85}$. Essa complexidade das interações que resulta do processo de harmonização ${ }^{86}$ demonstra a importância, no caso das dinâmicas centrífugas, que teriam lugar nos temas de domínio recalcitrante, do conceito de margem nacional de apreciação.

\section{A MARGEM NACIONAL DE APRECIAÇÃO}

A margem nacional de apreciação, como método do processo de interação do direito, é o melhor meio de preservar as diferenças e prestigiar os direitos humanos. Ela permite uma aproximação das práticas, por intermédio de uma reexame periódico das práticas nacionais, observando-se a evolução da sociedade e da ciência. Preserva-se a diversidade das práticas nacionais determinadas por fatores religiosos e morais, sem perder de vista uma futura possibilidade de aproximação de distintos ordenamentos jurídicos.

\footnotetext{
82 CHAIB, André Nunes. Os Direitos Fundamentais e a Possibilidade de uma Comunidade Internacional de Valores. Prismas: Dir., Pol. Publ. e Mundial., Brasília, v. 6, nº 1, p. 35-52, jan./jun. 2009, disponível em http://www.publicacoesacademicas.uniceub.br/index.php/prisma/article/view/ 701/618, acesso em 09 nov. 2010.

83 DELMAS-MARTY, Mireille. Les Forces Imaginantes du Droit (II). Le Pluralisme Ordonné. Éditions du Seuil, 2006, p. 71.

${ }^{84}$ DELMAS-MARTY, Mireille. Les Forces Imaginantes du Droit (II). Le Pluralisme Ordonné. Éditions du Seuil, 2006, p. 72.

${ }^{85}$ KOSKENNIEMI, M. Fragmentation of International Law: difficulties arising from the diversification and expansion of international law. Report of the Study Group of the International Law Commission. United Nations, p. 201.

${ }^{86}$ BELTRAME, Adriana; CHAIB, André Nunes; SILVA, René Marc da Costa. O Multiculturalismo e a Globalização como Princípios para uma Internacionalização do Direito. Padê, Brasília, v. 2, $\mathrm{n}^{\circ} 1$, p. 4-46, jan./jun. 2008. Disponível em http://www.publicacoesacademicas.uniceub.br/index. php/pade/article/viewFile/583/531. Acesso em 29 nov. 2010.
} 
Seria possível construir uma comunidade de direito sem uma comunidade de valores ou a universalização jurídica não é suficiente para a construção de uma sociedade de valores ${ }^{87}$ ? Hodiernamente, faz-se necessário pensar na existência de um diálogo intercultural, argumentativo e contraditório, que leve em conta as diferenças históricas, geográficas, de tradições filosóficas e religiosas etc. No entanto, nos hard cases do direito penal, esse diálogo não resolveria, e somente a existência de uma clara margem nacional de apreciação respeitaria as particularidades locais e atingiria uma maior legitimidade parlamentar na representação dos interesses de uma específica comunidade moral.

A ideia é mostrar que em casos como os acima estudados, não há como pensar em valores comuns, pois aspectos relacionados a fortes sentimentos humanos, religião, moral, ética, impedem que se chegue a um denominador comum $^{88}$. Haveria, então, uma necessidade de se interpretar o direito penal em harmonia com as tradições nacionais.

O princípio da proporcionalidade, do mesmo modo, não resolveria esse tipo de problema de difícil solução, pois o princípio é pensado para ser aplicado no caso concreto, com uma ponderação à luz das especificidades do caso e, no caso de direito penal, o assunto deveria ser tratado no plano abstrato, à luz da tipicidade ou não da conduta ${ }^{89}$.

Em tais hipóteses, a única saída seria deixar a análise de mérito da matéria na seara da margem nacional de apreciação $0^{90}$, como um mecanismo para conjugar o universalismo dos direitos do homem com o relativismo das tradições nacionais. A margem nacional permite uma certa lacuna para que se reporte à norma comum e uma certa diversidade entre os dispositivos nacionais, mas ainda haverá a possibilidade de um controle supranacional, por exemplo quanto à legalidade da medida, a existência de um recurso e a proporcionalidade da medida relacionando-se com a razão invocada. A norma é relativizada não somente no espaço, mas também no tempo.

Para evitar uma autonomia ilusória, poder-se-ia pensar em harmonizar os procedimentos e as regras de fundo, deixando à margem nacional de apreciação nacional as questões éticas que exigem do direito penal uma intervenção na seara da tipicidade ${ }^{91}$.

\footnotetext{
87 CHAIB, André Nunes. Os direitos fundamentais e a possibilidade de uma comunidade internacional de valores. Prismas: Dir., Pol. Publ. e Mundial., Brasília, v. 6, n. 1, p. 35-52, jan./jun. 2009, disponível emhttp://www.publicacoesacademicas.uniceub.br/index.php/prisma/ article/view/701/618, acesso em 09 nov. 2010.

88 DELMAS-MARTY, Mireille. Les Forces Imaginantes du Droit (II). Le Pluralisme Ordonné. Éditions du Seuil, 2006, p. 81.

${ }^{89}$ DINIZ, Geilza Fátima Cavalcanti. Teoria da Argumentação Jurídica e Love's knowledge no Caso da Antecipação do Parto do Feto Anencéfalo. In Revista de Informação Legislativa, a. 47, $\mathrm{n}^{\circ} 188$, out./dez. 2010, p. 263.

90 DELMAS-MARTY, Mireille. Les Forces Imaginantes du Droit (I). Le Relative et l'universel. La Couleur des Idées, 2004, p. 55.

${ }_{91}$ DELMAS-MARTY, Mireille. Les Forces Imaginantes du Droit (II). Le Pluralisme Ordonné. Éditions du Seuil, 2006, p. 20.
} 
Assim, por exemplo, poder-se-ia pensar em harmonizar questões quanto ao prazo para requerimento da autorização para a interrupção da gravidez, necessidade de perícia médica, confirmação do diagnóstico por mais de um médico, possibilidade de recurso (duplo grau de jurisdição), acesso psicológico e psiquiátrico à gestante, obrigação do Estado em arcar com as despesas de funeral etc.

Os textos sobre os direitos do homem revelam uma confusão entre moral comum e direito comum, substituindo um método dedutivo fundado sobre uma lógica formal descendente ao método inverso dos jurisconsultos romanos e dos juízes da common law, sem fazer distinção entre o direito escrito e a jurisprudência, de forma que os juízes deverão progressivamente reinventar um método dialético e indutivo para conjugar norma universal e relativismo nacional.

O assunto necessita de uma verdadeira reflexão filosófica - razão filosófica da moral ${ }^{92}$, pautada em normas de moral estabelecida e legitimidade, que imprescinde de um diálogo interdisciplinário, aberto e pluralista, impossível de ser alcançado em um cenário internacional, ao menos sob a forma de imposição. Como leciona Peter Häberle ${ }^{93}$, seria um pensamento possibilista, ou seja, pensar em e a partir de alternativas, em um procedimento chamado pelo autor de antonomásia e caracterizado pelo seguinte questionamento: que outra coisa poderia também ser em lugar do que é o que parece ser? O pensamento possibilista ou pluralista alternativo amplia o horizonte visual, dando espaço a outras e novas realidades, incompatível com a fixação de valores comuns.

E essa necessidade de uma maior abertura é necessária especialmente se analisarmos fenômenos como o women on web e women on waves, duas iniciativas de organizações não governamentais holandesas, país no qual o aborto é amplamente permitido, que rompem completamente as fronteiras nacionais e, respectivamente, vendem coquetel de medicamentos abortivos para qualquer lugar do mundo e promovem viagens para prática de aborto em alto mar. Verifica-se, com tais medidas, que atualmente podemos verificar a criação, dentro de um mesmo estado-nação, de grupos culturais, étnicos, religiosos, que se ligam a outros grupos de outros estados-nação, enfrentando os conceitos tradicionais de jurisdição e soberania.

A Corte elaborou sua doutrina da margem nacional de apreciação no caso Ireland v. Reino Unido. Considerou-se que os estados nacionais têm contato direto e contínuo com as pressões e necessidade do momento, de forma que as autoridades nacionais estão, em princípio, em uma melhor posição do que o juiz nacional para decidir. Entendeu-se que o art. $15, \S 1^{\circ}$ da

${ }^{92}$ CORTINA, A. Ética Mínima. Madrid: Tecnos; 1996.

${ }^{93}$ HÄBERLE, Peter. Pluralismo y Constitución. Estudios de Teoría Constitucional de la sociedad abierta. Estudio preliminar y traducción de Emilio Mikunda, Tecnos, 2008, p. 63. 
Convenção confere às autoridade nacionais essa margem de apreciação ${ }^{94}$. A Corte entende, ainda que a ausencia de um conceito europeu uniforme sobre moralidade deve fazer com que os países tenham um mínimo de poder discricionário ${ }^{95}$. A doutrina da margem nacional de apreciação foi uma resposta natural da Corte Europeia de Direitos Humanos às lacunas do direito e previsões de tratados a serem interpretados. A Corte indicou que há três razões para permitir que os Estados tenham certa discricionariedade: a natureza subsidiária da proteção internacional, o contato direto e contínuo dos estados com as forças vitais de seu país e a ausência de standards europeus comuns ${ }^{96}$. A Corte Européia de Direitos Humanos admite uma margem nacional de apreciação, considerando que os estados estão, em princípio, mais bem situados do que o juiz internacional para decidir determinados temas, em regra ligados a restrições de direitos fundamentais. Trata-se de uma espécie de direito à diferença para os Estados ${ }^{97}$.

A religião, portanto, tem um importante papel na discussão sobre os temas tormentosos do direito, como é o caso do aborto. A questão de quando a vida começa, por exemplo, tem sido construída pela religião desde tempos muito remotos, sendo que algumas religiões acreditam que a vida começa com a concepção, outras ao nascimento e há quem prefira deixar o tema para ser discutido de acordo apenas com as crenças individuais. A religião toma esse espaço não somente porque a ciência ainda não deu uma resposta definitiva ao tema, mas pela pressão que a religião sempre exerceu sobre o direito ${ }^{98}$.

A doutrina da margem nacional de apreciação tem uma fundação de balancear a uniformidade e a diversidade dentro do sistema internacional de proteção aos direitos humanos. O grande problema é a falta de critério na aplicação dessa doutrina pela CEDH. Quando se quer impor uniformidade, não se menciona a margem nacional de apreciação; quando se quer garantir a diversidade, aplica-se a margem nacional de apreciação ${ }^{99}$. Como a Convenção Europeia de Direitos Humanos não faz menção ao conceito

\footnotetext{
${ }^{94}$ Artigo $15 .^{\circ} 1$ - Em caso de guerra ou de outro perigo público que ameace a vida da nação, qualquer Alta Parte Contratante pode tomar providências que derroguem as obrigações previstas na presente Convenção, na estrita medida em que o exigir a situação, e em que tais providências não estejam em contradição com as outras obrigações decorrentes do direito internacional.

${ }^{95}$ DELMAS-MARTY, Mireille (Ed). The European Convention for the protection of human rights: international protection versus national restrictios. Trad. Cristina Chodkiewicz. Kluwer Academic Publiser, 1992, p. 308.

${ }^{96}$ CAMERON, Ian. National security and the European Convention on Human Rights. Londres: Kluer Law International, 2000, p. 444.

${ }^{97}$ DARNTON, Robert; DUHAMEL, Olivier. Democracia. Rio de Janeiro: Record, 2001, p. 168.

${ }^{98}$ MERRIMAN, Scott. A. Religion and the law in America: an Encyclopedia of Personal Belief and Public Policy. ABC-CLIO, 2007, p. 404.

${ }_{99}$ BREMS, Eva. The margin of appreciation doctrine of the European Court of Human Rights: Accomodating Diversity within Europe. In Human rights and diversity: area studies revisited . David P. Forsythe,Patrice C. McMahon(Ed), University of Nebraska, p. 82.
} 
de margem nacional de apreciação, a CEDH tem desenvolvido o conceito caso a caso, mas autores têm apontado que a margem de apreciação não tem sido aplicada de forma idêntica na interpretação dos artigos da Convenção ${ }^{100}$, de maneira que a margem nacional de apreciação se tornou uma ferramenta multifuncional à disposição da $\mathrm{CEDH}^{101}$.

Pode-se então afirmar que dentro dessa sistemática, o direito doméstico é o primeiro árbitro sobre os valores e moral que constituem o suporte de justificação para as regras domésticas ${ }^{102}$. Propõe que valores éticos e princípios sejam considerados nas declarações internacionais e estudos, sugerindo então cinco categorias de documentos: 1) documentos intergovernamentais, 2) relatórios de comissões internacionais e declarações de conferências internacionais, 3) projetos e pesquisas não governamentais, 4) afirmações de indivíduos, especialmente os participantes de encontros relacionados com o Projeto Ético Universal, 5) propostas relativas a tradições religiosas ${ }^{103}$.

A necessidade de esse repensar a internacionalização do direito decorre do fato de que não é a política, mas a própria sociedade civil que impulsiona a mundialização dos diferentes discursos fragmentados, até porque hoje em dia os grupos sociais diferenciados se encontram nos diversos países, não respeitando fronteiras, em um processo que alguns chamam de spill over. Assim, o direito internacional se desenvolve a partir de periferias sociais para o centro, formando assim a chamada Bukowina ${ }^{104}$ da sociedade mundial.

\section{CONCLUSÕES}

Samuel P. Huntington desenvolveu a teoria do choque de civilizações $^{105}$, asseverando que há uma necessidade de afirmação das identidades próprias das diversas civilizações, que gera relações conflituosas entre elas. Essa teoria ganhou grandes adeptos especialmente após o 11 de setembro de 2001. Esse choque de civilizações se deve, fundamentalmente, às polêmicas atuais em torno da bioética, da ética sexual e modelo de família e do lugar que a religião ocupa na vida pública ${ }^{106}$. Enquanto algumas culturas

\footnotetext{
100 MERRILLS, J. G. The development of international law by the European Court of Human Rights. Melland Schill Monographs in International Law, 1993, p. 151.

${ }^{101}$ YOUROW, Howard Charles. The Margin of Appreciation Doctrine in the Dynamics of European Human Rights Jurisprudence. Martinus Nijhoff Publishers, 1995, p. 195.

102 BARTH, William KurT. On Cultural Rights: the equality of nations and the minority legal tradition. Martinus Nijhoff Publishers, 2008, p. 180

${ }^{103} \mathrm{KIM}$, Yersu, Philosophy and the Prospects for a Universal Ethics, in God and globalization: religion and the powers of the common life, ed. Max L. Stackhouse,Peter J. Paris, 2000, p. 101.

104 TEUBNER, G. Global Bukowina. Legal pluralism in the World Society. In: Gunther Teubner (ed.), Global Law Without a State. Dartmouth, Aldershot 1997, p. 3-28.

105 HUNTINGTON, S.R, El Choque de Civilizaciones y la Reconfiguración del Orden Mundial, Paidós, Barcelona, 1997. En una línea similar: KAGAN, R., El retorno de la Historia y el fin de los sueños, Taurus, Madrid, 2008, p. 20.

106 PATTERSON, Eric. "Different Religions, Different Politics? Religion and Political Attitudes in Argentina and Chile." Journal for the Scientific Study of Religion 43, no. 3 (September 2004): 345-362. Academic Search Complete, EBSCOhost (accessed November 9, 2010), p. 103.
} 
consideram intangíveis os princípios da sacralidade da vida desde a concepção à morte natural e o repúdio entre as relações sexuais entre pessoas do mesmo sexo ou extramatrimoniais, atraem sobre si a ira de quem pretende a hegemonia cultural e acusa a visão oposta de ditadura do relativismo.

A religião, portanto, tem um importante papel na discussão sobre os temas tormentosos do direito, como é o caso do aborto. A questão de quando a vida começa, por exemplo, tem sido construída pela religião desde tempos muito remotos, sendo que algumas religiões acreditam que a vida começa com a concepção, outras ao nascimento e há quem prefira deixar o tema para ser discutido de acordo apenas com as crenças individuais ${ }^{107}$. A religião toma esse espaço não somente porque a ciência ainda não deu uma resposta definitiva ao tema, mas pela pressão que a religião sempre exerceu sobre o direito.

O papel do direito internacional deve ser o de garantidor, a cada indivíduo, da possibilidade de serem livres conforme os espaços culturais em que nasceram e foram criados ${ }^{108}$. O caminho talvez seja aquele traçado pela Corte Europeia de Direitos Humanos ${ }^{109}$, a qual, ao se pronunciar sobre se um aborto provocado por um médico, na França, em decorrência de erro, poderia ou não ser considerado um homicídio involuntário, isto é, um crime contra a pessoa. A Corte Europeia de Direitos Humanos, na decisão, abordou a diversidade de concepções existentes com relação ao momento inicial da vida humana, preferindo deixar o tratamento específico do tema ao poder discricionário dos Estados, mencionando trechos do parecer do Grupo Europeu de Ética, no qual se afirma que é delicado impor uma harmonização das legislações nacionais, especialmente devido à falta de consenso e inoportunidade de se pretender editar uma moral única. Foi a partir dessa decisão que a Corte Europeia de Direitos Humanos passou a adotar o conceito de margem nacional de apreciação dos Estados.

$E$ isso porque se começa a verificar que o problema da onipresença dos direitos humanos na política internacional é paradoxalmente compatível com uma crescente fluidez do seu conceito e uma permanente redefinição de seu conteúdo. A noção de direitos humanos somente tem sentido se se aceitar a ideia da "natureza humana", isto é, de uma ideologia de que os direitos humanos proíbem que as pessoas sejam tratadas de forma incompatível $\mathrm{cm}$ a sua dignidade, ou seja, de formas de impeçam o adequado desenvolvimento das potencialidades humanas naturais. Ora, mas o conceito de "natureza humana", assim como o de verdade moral,

${ }^{107}$ MERRIMAN, Scott. A. Religion and the law in America: an Encyclopedia of Personal Belief and Public Policy. ABC-CLIO, 2007, p. 404.

${ }_{108}^{1 A C U B}$, Marcela. Gender, Religion and Law. Disponível em <http://www.cardozolawreview.com/ content/30-6/IACUB.30-6.pdf>. Acesso em 10 fev. 2011.

${ }^{109}$ CEDH : Affaires Vo c. France, 8 juill. 2004. 
é cada vez menos admissível para a mentalidade relativista do ocidente pós-moderno ${ }^{110}$.

O neofeminismo, a ideologia de gênero, o multiculturalismo, tendem a considerar que quase nada é natural, que tudo é cultural e, portanto, variável e redefinível. Assim, ao mesmo tempo em que o movimento pro-direitos humanos se multiplica no mundo, desconstrói-se o conceito de natureza humana que o fundamentava. Questiona-se, portanto, o fundamento antropológico dos direitos humanos e se relativiza seu conteúdo, de forma que o proselitismo relativista do ocidente é uma "contradictio in adjecto", porque não se pode falar em uma natureza humana objetiva, da qual emanam imperativos morais.

A ética do consenso demonstra-se dissociada do atendimento das necessidades dos mais fracos, das minorias, que acabam por não participar de consenso algum ${ }^{111}$. Nas sociedades ocidentais contemporâneas, a hostilidade anticatólica não precisa necessariamente adotar a forma de persecução aberta. Os religiosos são objeto de uma forma sutil de discriminação: a chamada doutrina das razões públicas, que exclui a possibilidade de que os crentes façam valer nos debates jurídicos e políticos argumentos dependentes de suas convicções religiosas. As pessoas religiosas, portanto, acabam sendo reduzidas, na prática, a cidadãos de uma segunda categoria, afastados a abstardos do discurso da racionalidade e, por isso, não poderiam ter o direito de esperar que a legislação reflita seus pontos de vista morais.

A doutrina das razões públicas recebeu diversas formulações no pensamento jurídico-político contemporâneo; a mais influente delas foi a de John Rawls, em seu "Liberalismo político", no qual defente a tese do pluralismo racional, ou seja, uma base pública de justificação, neutra e racional, completamente afastada de aspectos metafísicos ${ }^{112}$. Rawls defende, portanto, a separação entre o político e o metafísico, para que se adotem critérios de justiça supostamente imparciais. O liberalismo rawlsiano, portanto, propõe um estado laico. Mas, se o estado se abstrai completamente das questões metafísica, podemos falar em legitimidade? Seria legítimo um estado que não levasse em consideração a crença e os valores morais de sua própria população?

No entanto, o tratamento que o próprio Rawls dispensa à questão do aborto é curiosa. Em nota de rodapé, afirma que a questão deve ser analisada

110 CONTRERAS, Franciso J. Cristianismo, Razón Pública y guerra. Disponível em http://web.ebscohost.com/ehost/pdfviewer/pdfviewer?vid=17\&hid=112\&sid=9bb3f265-13e9-9ebb648 893cc9f763d9\%40sessionmgr110, acesso em 09 nov. 2010.

${ }^{111}$ Os mais influentes representantes contemporâneos da ética laica -John Rawls, Ronald Dworkin, Thomas Nagel, Robert Nozick, Tim Scanlon, Judith Jarvis Thomson- militam unanimamente a favor do aborto e da eutanasia.

${ }_{112}$ RAWLS, John. Political Liberalism. Columbia Classics in Philosophy. Columbia University Press, 1996, p. 176.

DiREITOS FundAMENTAIS E E JUSTIÇA - ANO 5, N 16, P. 95-135, JUL./SET. 2011 
a partir de três valores políticos importantes: o respeito à vida humana, a perpetuação ordenada da comunidade política e a igualdade das mulheres com os homens, como cidadãos, e termina arfimando que o equilíbrio razoável entre esses valores findará proporcionando à mulher um direito devidamente qualificado a decidir se interrompe ou não sua gravidez durante o primeiro trimestre ${ }^{113}$. Ou seja, a visão de Rawls pode perfeitamente ser considerada tão carregada de valores como aquela dos ativistas pro-vida, assim como se pode concluir que as visões dos pensadores laicistas são visões de ateus ou agnósticos que, de qualquer modo, não são neutras, mas sim possuem valores subjacentes.

E assim sendo, a suposta visão neutra ou racional do tema pode, na realidade, estar impregnada de crenças materialistas, como se fosse a única aceitável do ponto de vista puramente político e então, na realidade, essa neutralidade do estado seria uma falácia, que prioriza as opiniões baseadas em uma visão ateia sem dar o mesmo espaço às opiniões religiosas. Portanto, a neutralidade do poder estatal é incompatível com a generalização política de uma visão do mundo laicista e, por isso, os cidadãos secularizados não podem negar, por princípio, aos conceitos religiosos seu potencial de verdade e nem podem negar aos seus co-cidadãos crentes o direito à realizar debates de cunho religioso nas discussões públicos. ${ }^{114}$

O próprio laicismo, estudado mais a fundo, demonstra ser uma doutrina sectária, com seus pressupostos metafísicos e morais, com seus mitos e, quem sabe rituais, porque também configura um tipo de crença. Assim, é preciso expandir a ideia de razão pública ${ }^{115}$ para que o debate envolva as crenças religiosas ou não religiosas, para que assim se alcance, verdadeiramente, uma perspectiva neutra. $\mathrm{E}$, no plano internacional, dado que um consenso seria impossível, caberia identificar as temáticas relativas a questões religiosas e morais em sentido mais forte - os domínios recalcitrantes e, exatamente nessa seara, deixar à margem nacional de apreciação a solução da controvérsia, evitando-se, assim, zonas de resistências e novas crises como aquela vivida em 11 de setembro de 2001.

Os casos estudados no presente trabalho, isto é, do tratamento dado à interrupção do feto anencéfalo nos Estados Unidos, na Argentina, no Brasil e na Alemanha nos permitiram concluir que o tema é profundamente marcado por valores religiosos, que permanecem escusos em uma aparente racionalidade do discurso jurídico, mas que na realidade é determinante no processo de tomada de decisão.

${ }^{113}$ RAWLS, John. Political Liberalism. Columbia Classics in Philosophy. Columbia University Press, 1996, p. 479.

${ }^{114}$ RATZINGER, Joseph; HABERMAS, Jürgen. Dialéctica de la Secularización. Sobre la Razon e la Religión. Trad. Isabel Blanco. Ediciones Encuentro, 2006, p. 47

${ }_{115}$ GEORGE, Robert P.; WOLFE, Cristopher (Ed.) Natural Law and Public Reason. Georgetown University Press, 2000, p. 70. 
No entanto, conclui-se também que, mesmo em países de tradição religiosa muito parecida, como o caso do Brasil e da Argentina, aspectos culturais e questões políticas fazem com que as decisões sejam díspares e há uma profunda discussão social dentro dos próprios países sobre esses domínios recalcitrantes, como se pretender uma unificação ou entrecruzamento? Por outro lado, países muito desenvolvidos e de vanguarda, como os Estados Unidos, determinam até mesmo a escolha de seus juízes pela opinião pessoal sobre esses temas e, outros, como a Holanda, são acusados fortemente por facções religiosas por causa de seu excesso de liberalismo. A saída, portanto, seria a harmonização como único processo possível de interação do direito internacional nos domínios recalcitrantes, excluindo-se, portanto, a unificação e o entrecruzamento, aquele pela impossibilidade, este pela ineficácia.

\section{REFERÊNCIAS BIBLIOGRÁFICAS}

ALEXY, Robert. Teoria da Argumentação Jurídica: a teoria dos discurso racional como teoria da justificação jurídica. São Paulo: Landy, 2001.

BARTH, William Kurt. On Cultural Rights: the equality of nations and the minority legal tradition. Martinus Nijhoff Publishers, 2008.

BAUMGART, Claudia. DEMOCRACY, DIVERSITY, AND CONFLICT: Religious Zionism and Israeli Foreign Policy. Peace Research Institute Frankfurt, CORNELL UNIVERSITY, PEACE STUDIES PROGRAM, disponível em http://www.einaudi.cornell.edu/peaceprogram/publications/occasional_papers/Zineckerfinal.pdf, acesso em 02 nov. 2010.

BEER, Joop de; DEVEN, Freddy. Diversity in Family Formation: the 2nd demographic transition in Belgium and the Netherlands., Springer; 1st edition, 2000.

BELLAH, Robert Neelly. Civil Religion in America. Journal of the American Academy of Arts and Sciences 96 (1): 1-21. Disponível em http://www.robertbellah.com/ articles_5.htm. Acesso em 30 nov. 2010.

BELTRAME, Adriana; CHAIB, André Nunes; SILVA, René Marc da Costa. O Multiculturalismo e a Globalização como Princípios para uma Internacionalização do Direito. Padê, Brasília, v. 2, no 1, p. 4-46, jan./jun. 2008. Disponível em http://www.publicacoesacademicas.uniceub.br/index.php/pade/article/viewFile/583/51. Acesso em 29 nov. 2010.

BIDART, G. Derecho Constitucional y Bioética en Relación con la Vida Humana. Revista Jurisprudencia Argentina 1998; 6113 (Num. Esp.): 12-18.

BIJDTERVEL, SOPHIE, C. Van. Freedom of Religion in the Netherlands. Brigham Young University Review, 1995, v. 2, p. 555, 29 p. disponível em http://web.ebscohost.com/ ehost/delivery?vid=10\&hid=9\&sid=92f90, acesso em 20 out. 2010.

BODÉÜS, Richard. Aristóteles, a Justiça e a Cidade. São Paulo: Ed. Loyola, 2007.

BOGDANDY, A. V. e DELLAVALLE, S. Universalism and Particularism as Paradigms of International Law. IILJ Working Paper, 2008.

BREMS, Eva. The Margin of Appreciation Doctrine of the European Court of Human Rights: Accomodating Diversity within Europe. In Human rights and diversity: area studies revisited. David P. Forsythe,Patrice C. McMahon(Ed), University of Nebraska. 
BUSATO, Paulo César. Tipicidade Material, Aborto e Anencefalia. Disponível em <http://www2.mp.ma.gov.br/ampem/artigos/25.\%20Anencefalia_e_\%20aborto.pdf >. Acesso em 10 fev. 2011.

CAMERON, Ian. National Security and the European Convention on Human Rights. Londres: Kluer Law International, 2000.

CARBAJAL, Mariana. La Situación del Aborto en la Argentina. Un Debate Pendiente. Debate Feminista 34, no 17 (October 2006): 143-157. Academic Search Complete, EBSCOhost (accessed November 9, 2010).

CARDIN, Valéria Silva Galdino. "DO ABORTO EUGÊNICO". Disponível em www.conpedi.org/manaus/arquivos/anais/brasilia/14_286.pdf, acesso em 05 jul. 2010. CARDOSO, Clodoaldo Meneguello. Tolerância e seus Limites. Um Olhar Latinoamericano sobre Diversidade e Desigualdade. São Paulo: Editora Unesp, 2008.

CARVALHO, Teresa Robichez de. A Antecipação Terapêutica de Parto na hipótese de Anencefalia Fetal: estudo de casos do Instituto Fernandes Figueira e a interpretação constitucional do Tribunal de Justiça do Estado do Rio de Janeiro e do Supremo Tribunal Federal. Disponível em <http://www.dominiopublico.gov.br/ pesquisa/ DetalheObraForm.do?select_action=\&co_obra=126556>. Acesso em 27 jul. 2010.

CHAIB, André Nunes. Os Direitos Fundamentais e a Possibilidade de uma Comunidade Internacional de valores. Prismas: Dir., Pol. Publ. e Mundial., Brasília, v. 6, n. 1, p. 35-52, jan./jun. 2009, disponível em http://www.publicacoesacademicas.uniceub.br/index. php/prisma/article/view/701/618, acesso em 09 nov. 2010.

CHORUS, Jeroen M. J.; GERVER, P. H. M.; HONDIUS,E. H.; RECHTSVERGELIJKING, Nederlandse Vereniging voor (ed). Introduction to Dutch law. Kluwer Law International, 2006.

COBRA, Rubem Queiroz. Vida, Época, Filosofia e obras de Benedito Espinosa. Disponível em http://www.cobra.pages.nom.br/fmp-spinoza.html, acesso em 02 nov. 2010.

COLE, George D. FRANKOWSKI, Stanislaw. Abortion and Protection of the Human Fetus: legal problems in a cross-cultural perspective (Current and Legal Issues in International and Comparativ). University of Santa Clara. Institute of International and Comparative, 1987.

CONTRERAS, Franciso J. Cristianismo, Razón Pública y Guerra. Disponível em http://web.ebscohost.com/ehost/pdfviewer/pdfviewer?vid=17\&hid=112\&sid=9bb3f26513e9-49eb-b648-893cc9f763d9\%40sessionmgr110, acesso em 09 nov. 2010.

CORTINA, A. Ética Mínima. Madrid: Tecnos; 1996.

DARNTON, Robert; DUHAMEL, Olivier. Democracia. Rio de Janeiro: Record, 2001.

DELMAS-MARTY, Mireille (Ed). The European Convention for the Protection of Human Rights: international protection versus national restrictios. Trad. Cristina Chodkiewicz. Kluwer Academic Publiser, 1992.

DELMAS-MARTY, Mireille. Les Forces Imaginantes du Droit (I). Le Relative et l'universel. La Couleur des Idées, 2004.

DELMAS-MARTY, Mireille. Les Forces Imaginantes du Droit (II). Le Pluralisme Ordonné. Éditions du Seuil, 2006.

DINIZ, Geilza Fátima Cavalcanti. Teoria da Argumentação Jurídica e love's knowledge no caso da Antecipação do Parto do feto Anencéfalo. In Revista de Informação Legislativa, a. 47, n 188 , out./dez. 2010, p. 255-276. 
DORNAS. Danilo Santos. A Separação entre a Filosofia e a Teologia segundo Spinoza. Revista Eletrônica Print by FUNREI. Metavnoia. São João del-Rei, $\mathrm{n}^{\circ} 3$. p. 55-59, jul. 2001 Disponível em http://www.funrei.br.publicações/ Metavnoia, acesso em 03 nov. 2010.

DUPUY, Pierre-Marie. L'unité de l'ordre Juridique International : cours général de droit international public (2000) / par Pierre-Marie Dupuy. Recueil des cours, Volume 297 (2002).

DWORKIN, Ronald. Domínio da Vida: aborto, eutanásia e liberdades individuais. São Paulo: Matins Fontes, 2009.

GEORGE, Robert P.; WOLFE, Cristopher (Ed.) Natural Law and Public Reason. Georgetown University Press, 2000.

GOMES, Luiz Flávio. Teoria da Imputação Objetiva e Aborto Anencefálico: atipicidade material do fato. Disponível em <http://www.lfg.com.br/artigos/art_aborto_lfg.pdf>. Acesso em 10 fev. 2011.

GONÇALVES, Tamara Amoroso. LAPA, Thais de Souza. Aborto e Religião nos Tribunais Brasileiros. Coordenação de Tamara Amoroso Gonçalves. São Paulo: Instituto para a Promoção da Equidade, 2008.

GREEN, Ronald. Religion and Moral Reason. A New Method for Coparative Study. Nova Iorque: Oxford University Press, 1988.

GRIFFITHS, John Griffiths; BOOD, Alex; WEYERS,Heleen. Euthanasia and law in the Netherlands. Amsterdã Universtiy Press, 1998.

HÄBERLE, Peter. Pluralismo y Constitución. Estudios de Teoría Constitucional de la Sociedad Abierta. Estudio preliminar y traducción de Emilio Mikunda, Tecnos, 2008. HABERMAS, Jürgen. A Era das Transições. Rio de Janeiro: Tempo Brasileiro, 2003. HERRERO, Silvina. Adelantamiento del parto por Anencefalia del feto. Tesina № 192, apresentada à Facultad de Derecho y Ciencias Sociales, Carrera de Abogacía. Disponível em www.ub.edu.ar/investigaciones/tesinas/192_herrero.pdf, acesso em 03 jul. 2010.

HOFFMANN, John P., and Sherrie Mills Johnson. 2005. Attitudes Toward Abortion Among Religious Traditions in the United States: Change or Continuity? Sociology of Religion 66, $\mathrm{n}^{\circ}$ 2: 161-182. Academic Search Complete, EBSCOhost (accessed November 9, 2010).

HOOFT, Pedro F. Anencefalia: consideraciones bioéticas y jurídicas. Acta bioethica, versión On-line ISSN 1726-569X, Acta bioeth. v. $6 n^{\circ} 2$ Santiago dic. 2000. Disponível em http://www.scielo.cl/scielo.php?pid=S1726-569X2000000200006\&script=sci_arttext, acesso em 05 jul. 2010.

HTUN, Mala. Abortion Politics and Policy in Argentina, Brazil, and Chile. Conference Papers -- American Political Science Association (August 28, 2002): 1-47. Academic Search Complete, EBSCOhost (accessed November 9, 2010).

HUNTINGTON, S.R, El Choque de Civilizaciones y la Reconfiguración del Orden Mundial, Paidós, Barcelona, 1997. En una línea similar: KAGAN, R., El retorno de la Historia y el fin de los sueños, Taurus, Madrid, 2008.

HUNTINGTON, Samuel P., The Clash of Civilizations and the Remaking of World Order, New York, Simon \& Schuster, 1996.

IACUB, Marcela. Gender, religion and law. Disponível em $<$ http://www.cardozolawreview.com/content/30-6/IACUB.30-6.pdf>. Acesso em 10 fev. 2011. 
Icon Group. Abortions: Webster's Quotations, Facts and Phrases. California: Icon Group International, 2008.

KIM, Yersu, Philosophy and the Prospects for a Universal Ethics, in God and globalization: religion and the powers of the common life, ed. Max L. Stackhouse, Peter J. Paris, 2000.

KOSKENNIEMI, M. Fragmentation of International Law: difficulties arising from the diversification and expansion of international law. Report of the Study Group of the International Law Commission. United Nations.

KOSKENNIEMI, Martti. The Gentle Civilizer of Nations: The Rise and Fall of International Law. Cambridge: Cambridge University Press, 2001.

LOPES, Jaime Ferreira. Frente Contrária ao Aborto leva Vantagem. Brasil sem aborto. Disponível em http://www.brasilsemaborto.com.br/destaques.asp?op=1\&id=147. Acessado em 02 fev. 2011.

MENEM, Carlos. Discurso del Presidente Menem en el acto en conmemoración del "Día Nacional del Niño por Nacer", Decreto 1406/98, realizado en el Teatro Coliseo, disponível em <http://www.vidahumana.org/dia/discurso.html>, acesso em 11 fev. 2010.

MERRILLS, J. G. The development of international law by the European Court of Human Rights. Melland Schill Monographs in International Law, 1993.

MERRIMAN, Scott. A. Religion and the law in America: an Encyclopedia of Personal Belief and Public Policy. ABC-CLIO, 2007.

MEZIARA, Flávia Corrêa. Anencefalia: análise crítica nos âmbitos médico e legal. Disponível em: <http://www.dominiopublico.gov.br/pesquisa/DetalheObraForm.do? select_action=\&co_obra=116857>. Acesso em 27 jul. 2010.

MORON, A. Medicina fetal na prática obstétrica. São Paulo: Santos Editora, 2003.

MOUFFE, Chantal. The return of the political. Londres: Verso, 1993, 2005.

NUSSBAUM, Martha C. Love's knowledge. Essays on philosophy and literature. New York: Oxford University Press, 1990.

NUSSBAUM, Martha C. Poetic Justice. The literary imagination and public life. Beacon Press Books, 1995.

OLIVEIRA, Nythamar. Habemus Habermas: $O$ universalismo ético entre o naturalismo e a religião. Porto Alegre: Veritas, v. 54, n. 1, jan/mar 2009, p. 217-237.

OUTSHOORN, Joyce. Policy-Making on Abortion: Arenas, Actors and Arguments in the Netherlands. In Abortion politics, women's movements, and the democratic state: a comparative study of state feminism. Dorothy Mc. Bride Stetson (Ed), Ofxord University Press, 2003.

PATTERSON, Eric. "Different Religions, Different Politics? Religion and Political Attitudes in Argentina and Chile." Journal for the Scientific Study of Religion 43, no. 3 (September 2004): 345-362. Academic Search Complete, EBSCOhost (accessed November 9, 2010), p. 103.

PINTER, Aubeny E, Bartfai G, Loeber O, Ozalp S, Webb A. Accessibility and availability of abortion in six European countries. European Journal of Contraception \& Reproductive Health Care [serial online]. March 2005;10(1):51-58. Available from: Academic Search Complete, Ipswich, MA. Accessed November 2, 2010.

RANDAXHE, Fabienne. 2007. Religion, politique et régulation juridique aux ÉtatsUnis. French Politics, Culture \& Society 25, no. 3: 19-36. Academic Search Complete, EBSCOhost (accessed November 9, 2010). 
RATZINGER, Joseph. HABERMAS, Jürgen. Dialéctica de la secularización. Sobre la razon e la religión. Trad. Isabel Blanco. Ediciones Encuentro, 2006.

RAWLS, John. Political liberalism. Columbia Classics in Philosophy. Columbia University Press, 1996.

REAGAN, James E. Ethics Consultation: Anencephaly and Organ Donation. The Journal of Law, Medicine \& Ethics. Disponível em <http://web.ebscohost.com/ehost/pdfviewer/ pdfviewer?vid=10\&hid=11\&sid=5a4f5fbb-4b34-4aaf-9e98c82088bad4ba\%40session mgr13>. Acesso em 27 jul. 2010.

SAN JOSÉ, Daniel García. Unilateralismo y multilateralismo como concepctos de geometria variable en la sociedad internacional poscontemporánea. Disponível em www.reei.org., acesso em 05 nov. 2010.

SERAFINI, Anthony. 1993. Is Coma Morally Equivalent to Anencephalia?. Ethics \& Behavior 3, no. 2: 187. Academic Search Complete, EBSCOhost. Acesso em 27 jul. 2010. SIMON, Rita James. A Comparative Perspective on Major Social Problems. Lexington Books, 2001.

TEUBNER, G. e FISCHER-LESCANO, A. Regime Collisions: the vain search for legal unity. In the fragmentation of international law in Michigan Journal of International Law, 2003/2004, p. 999-1046.

TEUBNER, G. Global Bukowina. Legal Pluralism in the World Society. In: Gunther Teubner (ed.), Global Law Without a State. Dartmouth, Aldershot 1997, p. 3-28.

THOMAS, Scott. Religion and International Conflict. In Religion and International Relations, Ed. K. R. Dark, Palgrave, 2000.

YOUROW, Howard Charles. The Margin of Appreciation Doctrine in the Dynamics of European Human Rights Jurisprudence. Martinus Nijhoff Publishers, 1995. 